\title{
Productive vs. residential economy: Factors behind the recovery of rural areas in socioeconomic decline
}

\author{
David Peón Pose*a / Xosé Manuel Martínez-Filgueirab / Edelmiro López-Iglesias ${ }^{\mathrm{c} 1}$ \\ a Universidade da Coruña - Departamento de Empresa \\ b Universidade da Coruña - Departamento de Economía \\ c Universidade de Santiago de Compostela - Departamento de Economía Aplicada
}

Received: 14 April 2020 / Accepted: 31 July 2020

\begin{abstract}
The analysis and explanation of the diverse rural dynamics might help to design better targeted rural development policies. We focus on Galicia (Spain) as a case study of a region in demographic decline, in order to trace what factors are associated with the recovery of specific rural areas. Since demographic ageing and depopulation are often an inheritance from strong migration processes in the past, and the resulting imbalances, we use a statistical method by Martínez Filgueira, Peón \& López Iglesias (2017) to remove the demographic drag due to past migration. We then perform a multivariate statistical analysis that explores the relationship of the municipalities' population growth beyond the drag with a total of 50 indicators in 10 domains, including territorial, such as infrastructures and remoteness, economic diversification, the profitability of business activities, human capital, and quality of life indicators, such as access to public services and trends of rurbanisation. We obtain mixed results for the dichotomy 'entrepreneurship versus quality of life'. The main findings are the evidence of agglomeration economies -the distance to the main cities and the size of the county capital- and the positive impact of socio-economic variables such as disposable income and stock of human capital. In addition, we obtain a correspondence between rural areas in recovery and a higher density of companies and self-employment in the services sector.
\end{abstract}

Keywords

Rural development / Entrepreneurship / Intra-rural divides / PCA / Galicia.

\section{Economía produtiva vs. residencial: factores tras a recuperación de áreas rurais en declive socioeconómico}

\section{Resumo}

A análise e explicación das diversas dinámicas rurais poderían contribuír ao deseño dunhas políticas de desenvolvemento rural mellor orientadas. Centrámonos en Galicia como caso de estudo dunha rexión en declive demográfico, co fin de identificar os factores asociados coa recuperación dalgunhas zonas rurais. Dado que envellecemento e despoboamento adoitan ser herdanza de fortes procesos migratorios do pasado, e dos desequilibrios resultantes, empregamos o método estatístico de Martínez Filgueira, Peón e López Iglesias (2017) para eliminar a deriva demográfica debida á migración pretérita. Logo, realizamos unha análise estatística multivariante que explora a relación entre o crecemento demográfico dos distintos concellos, máis alá da deriva, cun total de 50 indicadores en 10 dominios, tanto territoriais como de infraestruturas ou afastamento, diversificación económica, rendibilidade das empresas, capital humano ou de calidade de vida, como do acceso a servizos públicos ou de tendencias de 'rurbanización'. Obtemos, así, unha evidencia mixta da dicotomía "emprendemento vs. calidade de vida". Os principais resultados son as economías de aglomeración -distancia ás cidades e tamaño da capital de comarca- e o impacto positivo de variables socioeconómicas como renda dispoñible e stock de capital humano. Ademais, obtense unha correspondencia entre as zonas rurais en recuperación e unha maior densidade de empresas e autónomos no sector servizos.

Palabras clave

Desenvolvemento rural / Emprendemento / Divisións intra-rurais / PCA / Galicia.

Códigos JEL: 018, R58, M21, J11.

\footnotetext{
* Corresponding author: david.peon@udc.es

1 This research has received the funding of the Program for the "Consolidation and Structuring of Competitive Research Units - Research Networks (Redes de Investigación)" (Ref. ED341D R2016/014), Proxectos Plan Galego IDT, from the Xunta de Galicia (Spain).
} 


\section{Introduction}

Many rural areas in Europe continue to exhibit a significant lag in terms of economic development and social well-being (Akgün, Baycan \& Nijkamp, 2015; Spoor, 2013), having an impact on their population structure and dynamics (European Commission, 2013). The design of effective public policies to promote social and territorial development and cohesion must be based on an analysis of the factors that lie behind successful experiences. In this respect, it is convenient to replace the traditional urban-rural dichotomy by the analysis of intra-rural divides (Rizzo, 2016): the interpretation of the diverse rural dynamics, with some rural areas performing much better than others and, in some cases, even better than urban areas (Bryden \& Munro, 2000), might be helpful for the design of rural development policies.

In the analysis of factors behind intra-rural divides, researchers recurrently consider geographical and territorial dimensions (Salvati \& Carluci, 2016; Smailes, Argent \& Griffin, 2002), rurbanisation (Eliasson, Westlund \& Johansson, 2015), employment and economic diversification (e.g., Marsden \& Sonnino, 2008), amenities and agritourism (Figueiredo, 2009; Phelan \& Sharpley, 2011), entrepreneurship and business growth (Li, Goetza, Partridge \& Fleming, 2016; Stephens, Partridge \& Faggian, 2013), and access to public services and better institutional governance (Sánchez-Zamora, Gallardo-Cobos \& Ceña-Delgado, 2014). These are summarized in the classic dichotomy of what should come first: fostering business activities and entrepreneurship in areas where socioeconomic indicators are weak, versus ensuring higher quality of life standards for residents in rural areas. The first option considers two directions (Barbut, 2009): the "productive economy", with the logic of boosting the competitiveness of the local economy in order to sell goods and services outside the rural territory, and the "residential economy", which sells them locally instead, seeking to create local jobs attracting residents, tourists and retirees (Bureau, 2016). Alternatively, the quality-of-life strategy works in the same direction as the residential economy, providing residents and visitors with access to public services and facilities of standards similar to those in urban areas.

We aim to contribute to this literature with a case study, Galicia (Spain), a paradigmatic example of an aged region in demographic decline, resulting from an unbalanced demographic structure inherited from strong migration processes since the $19^{\text {th }}$ century and especially during the period $1950-1975$. The case study might easily apply to other regions with a similar background: history may represent a heavy burden, particularly in rural areas, when they experienced large migration processes in the past. The consequences of population decline are often self-reinforcing, bringing about more population decline (Elshof, van Wissen \& Mulder, 2014).

Thus, the first part of our research is devoted to identify and remove the negative effect from past migration, following Martínez Filgueira et al. (2017) methodology. We apply that statistical treatment to all the 315 Galician municipalities to estimate the residuals of their demographic drag. Positive residuals identify municipalities that, despite possibly losing more population in the last two decades (1991-2011), exhibit, at least, a partial, true recovery, as they are being able to moderate or even reverse the depopulation process inherited from the past.

Then, in the second part of our research, we focus on the 264 municipalities in Galicia that are classified as rural according to DEGURBA standards (Instituto Galego de Estatística [IGE], 2011), to perform a principal component analysis (PCA) on a series of dimensions, including business performance and quality of life indicators, among others. By obtaining the factors that are related to population performance, measured through the residuals beyond the drag, we trace the dimensions that better explain the ability of rural areas to overcome the processes of ageing and depopulation. We obtain relevant results in two realms: territorial (the distance to the main urban areas and the population of the county capital) and socio-economic conditions (the ratio of university graduates and tdisposable income). Finally, a correspondence between rural areas in recovery and a higher density of companies and self-employment in the services sector is also observed.

The structure of the article is as follows. In Section 2, we analyse the depopulation process observed in the rural areas of Galicia, and obtain, for the period 1991-2011, the residuals of the demographic drag 
inherited from past migration processes at municipal level. Section 3 provides a multivariate statistical analysis devoted to interpret the factors that would explain the recovery of some rural areas verified in the previous data. Finally, Section 4 concludes. Additional information regarding methodology and econometric results may be found in the Supplementary Material (SM).

\section{The depopulation process of rural areas in Galicia in the recent decades and the residuals of the demographic drag}

\subsection{Recent demographic dynamics in Galicia (1991-2011)}

Galicia, in the North-West of the Iberian Peninsula, is a NUTS 2 region and one of the seventeen Autonomous Communities in Spain, with an extension similar to that of Belgium (about 30,000 square kilometres)with a population of 2.75 million inhabitants. It has historically lagged Spain in terms of population and GDP growth, persistently losing relative weight. The GDP per capita by 2014 was $80 \%$ of the EU-28 average in PPS terms, down from 92.3\% in 2009 (Xunta de Galicia, 2014).

What makes Galicia an interesting case study is that it represents a region in demographic decline. The average age of the population is four years higher than that of Spaniards and Europeans, and the fertility rate is among the lowest in the world (1.07 children per woman), contributing to a strongly negative vegetative balance ( -3.03 per thousand). Projections estimate that Galicia might lose a million inhabitants by 2050 (Xunta de Galicia, 2013). The dynamics of rural areas is even worse. Since the midtwentieth century, Galicia experienced a late and abrupt agricultural sector decline, reducing its share in total employment from $70 \%$ to less than 5\%. This intense sectoral restructuring resulted in a reduction of total employment, leading, at the same time, to strong rural-urban migration flows within the region (López Iglesias, 1995). Today, almost $70 \%$ of the population lives in $15 \%$ of the territory, a line in the West known as the Eixo Atlántico that goes from the North to the Portuguese border in the South and includes the largest cities of A Coruña and Vigo (about 300,000 inhabitants each) and the administrative capital, Santiago de Compostela - see Figure 1.
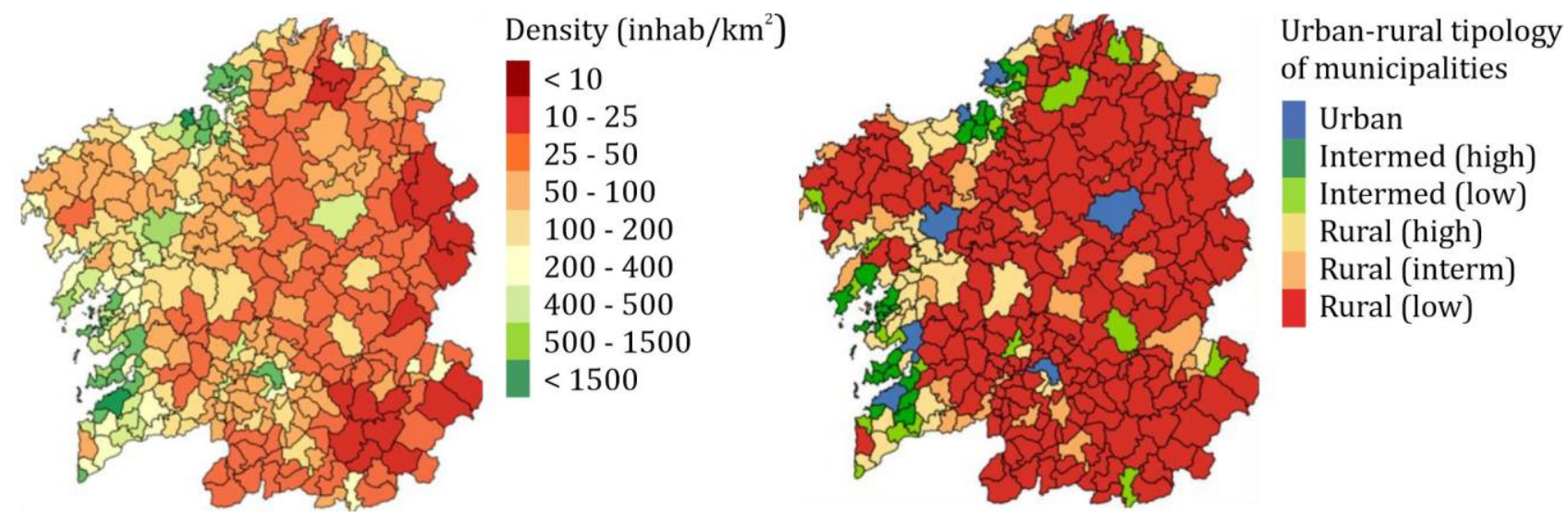

Figure 1. Territorial distribution of the Galician population. Density by municipalities 2011 and urban-rural typology (DEGURBA). Source: Own elaboration. Data: Instituto Nacional de Estadística (INE), Census 2011; IGE (2011).

As a result of past migration flows, rural areas inherited an unbalanced demographic structure that has conditioned their dynamics in recent decades. Figure 2 shows the population change of 
each municipality from 1991 to 2011 -which we denote DEPOP $_{91-11}$. The demographic dynamics continue to favour the concentration of the Galician population in the West, with the exceptions being the Northern coastal area, the two inner capitals of province -Lugo and Ourense- and a few villages of intermediate size. We may see the inner Galicia experiencing a strong depopulation process, with the most severe examples often related to municipalities in the mountains -to the East and South. This performance is difficult to reverse, as it is not caused by continued negative migration flows, but by the negative vegetative balance due to a demographic burden that is the consequence of past migrations (López Iglesias, 2013). We analyse this negative effect next.

EMIG50-91

Annualized growth rate $(\%)$

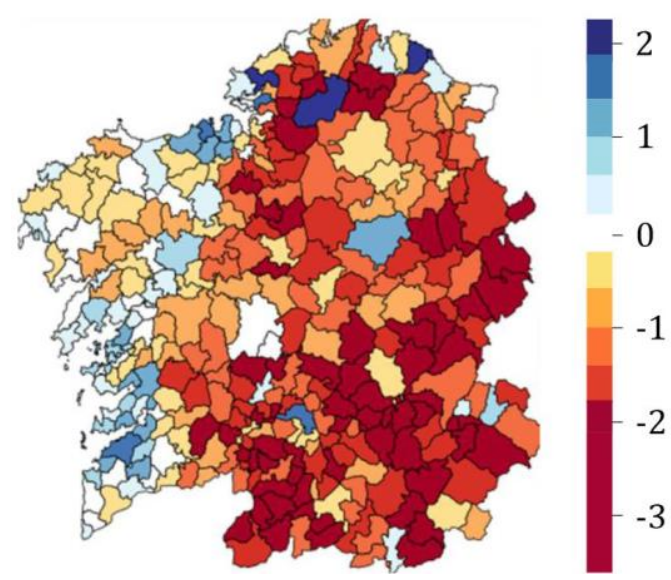

DEP0P91-11

Annualized growth rate $(\%)$

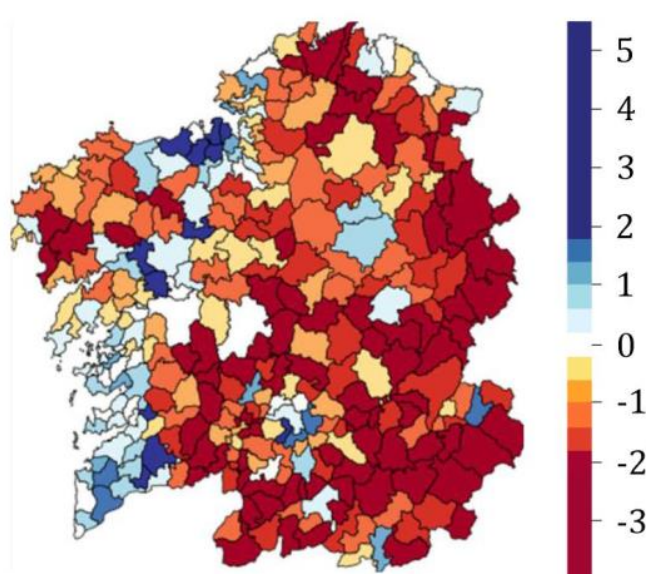

Figure 2. Population change of Galician municipalities. Years 1950-1991 (EMIG50-91) and 1991-2011 (DEPOP91-11). Source: Own elaboration. Data: INE, Census 1950, 1991, 2011.

Based on these initial findings, we follow Martínez Filgueira et al. (2017) methodology to set this hypothesis: the depopulation of rural municipalities in recent decades is due, to a large extent, to the demographic structure in early 1990s and this, in turn, is a consequence of past migration during the period 1950-1991. Thus, for changes in population, we retain three key dates: 1950, 1991 and 20112. The first one represents the beginning of the last historical migration period in Galicia that started in the 1950s and stopped after the 1970s crisis due to a sudden cut in the number of migrants to Europe. However, part of that migration does not appear in the official statistics until the 1991 Census -reflected in a significant net migration officially recorded in the 1981-1991 decade (Fernández Leiceaga \& López Iglesias, 2000). Finally, we use 2011 since this represents the last Census available.

Consequently, we define the variable $\mathrm{EMIG}_{50-91}$ as the annualized percentage of population change between 1950 and 1991, a proxy of the strong emigration in these four decades and, particularly, in the 1950-1975 period. We may appreciate a widespread population decline, where three quarters of the Galician territory saw its human potential diminished -see Figure 2. A dual pattern was developed: municipalities with a population density above 200 inhab $/ \mathrm{km}^{2}$ by 1950 increased or hardly lost population, while only a few exceptions below 150 inhab $/ \mathrm{km}^{2}$ could prevent population loss.

\footnotetext{
${ }^{2}$ Any changes in the municipality map of Galicia since 1950 were taken into account (see Míguez Macho, 2013 for a review). See the SM for a detailed description of sources and relevant details in data processing.
} 


\subsection{The residuals of the demographic drag (1991-2011)}

We firstly demonstrate the decisive role of the migration flows occurring from 1950 to 1991 as determinant of the demographic structure of the municipalities in 1991. Consequently, we then use it to obtain the residuals of the demographic drag (the population dynamics in the period 1991-2011 after discounting the dragging effect from the past).

- Step 1. Historic migration, reflected in the population change 1950-1991 (EMIG50-91), as a determinant of the demographic structure of municipalities in 1991.

We test the hypothesis that the variable EMIG $_{50-91}$ explains the differences in the demographic structure of the Galician municipalities in 1991, and, particularly, the heavily skewed structure we find (to different degrees) in rural municipalities. We analyse the correlation of EMIG50-91 with the demographic variables mean age (d1), the percentage of population under $20(\mathrm{~d} 2)$, the percentage of population over $65(\mathrm{~d} 3)$, the elderly dependency ratio (d4), the $85+$ over $65+$ ratio (d5), the agedependency ratio (d6), the labour force structure (d7) and the labour force replacement (d8). Results are provided in Table A1 in the SM.

Overall, the results confirm the hypothesis: correlations of $75 \%$ to $90 \%$, significantly different from zero, and signs of consistent interpretation. The only exception is a correlation coefficient of -0.16 with variable $\mathrm{d} 5$ (the percentage of population 85 years old or more to the group of 65 or more), which makes sense, since this ratio would be a consequence of demographic phenomena before 1950. Higher correlation levels are observed with age structure ( $\mathrm{d} 1$ and $\mathrm{d} 3$ with -0.89 , and $\mathrm{d} 2$ with +0.86$)$. Then, with correlation coefficients higher than 0.80 , indicators that reflect the aging of population ( $\mathrm{d} 4$ and $\mathrm{d} 8$ ), and with coefficients above 0.75 those of the structure of active population (d6 and d7). These results support using EMIG $_{50-91}$ as a synthetic indicator or proxy of the demographic drag effect -i.e. the inertia of past population dynamics. However, we must see whether it is more appropriate to use $\mathrm{EMIG}_{50-91}$ or any of the indicators of the demographic structure in 1991. We carry out this analysis in the next step.

\section{- Step 2. Testing the validity of $\mathrm{EMIG}_{50-91}$ as the best proxy of demographic drag}

We follow Martínez Filgueira et al. (2017) to first observe, in Table A1, that the correlation between EMIG $_{50-91}$ and DEPOP $_{91-11}$ is strong as well, close to $65 \%$, significant and of consistent interpretation. The validity of EMIG $_{50-91}$ as a proxy of the demographic drag is then tested through the goodness of fit for different regressions on DEPOP ${ }_{91-11}$. We perform a selection of variables for the regression DEPOP ${ }_{91-11}$ to $\mathrm{EMIG}_{50-91}$ and the demographic variables d1 to d8, indicators of the demographic structure in 1991. As selection criteria we use BIC and Mallows $\mathrm{Cp}$ for regressions with one or two regressors, taking the explanatory power of the model in consideration - see Table A2 in the SM.

We find $\mathrm{DEPOP}_{91-11}=\mathrm{f}\left(\mathrm{EMIG}_{50-91}\right)$ is the regression that best fits the recent population trends, together with the regressions that include $\mathrm{d} 2$ and $\mathrm{d} 3$ (percentage of younger than 20 and older than 65). The goodness of fit of regression DEPOP $91-11=f\left(E I_{50-91}\right)$ is almost identical in terms of $R^{2}$ to the regression with best results - the one that uses $\mathrm{d} 2$ as a regressor - but introducing $\mathrm{EMIG}_{50-91}$ and $\mathrm{d} 2$ together does not add much. It would perhaps make sense to use EMIG ${ }_{50-91}$ and d5, since these two variables are not correlated. However, the regression barely gives additional information, $\mathrm{d} 5$ appears to be non-significant, and the adj- $\mathrm{R}^{2}$ worsens.

- Step 3. The population performance beyond the demographic drag

The significant correlation between EMIG $_{50-91}$ and DEPOP $_{91-11}$ indicates that the population dynamics at the municipal level in the period 1991-2011 are strongly affected by the migration flows in the 
previous decades. However, the value (0.65) of the correlation coefficient, far from one, indicates relevant variations across municipalities with regard to previous trends, and is lower than the correlation at the county level, 0.83 (Martínez Filgueira et al., 2017) -which indicates that Galician counties hide relevant differences in the behaviour of the municipalities within ${ }^{3}$.

Hence, we move on to identify to what extent the dynamics exhibit new developments with regard to previous trends. This is what the analysis of the regression residuals allows us to do. We define variable RESID ${ }_{91-11}$ as the residuals of the regression DEPOP $_{91-11}=f\left(E\right.$ IIG $\left._{50-91}\right)$. They provide the demographic performance of the Galician municipalities once the drift from past migrations is discounted. Figure 3 shows the residuals RESID ${ }_{91-11}$.

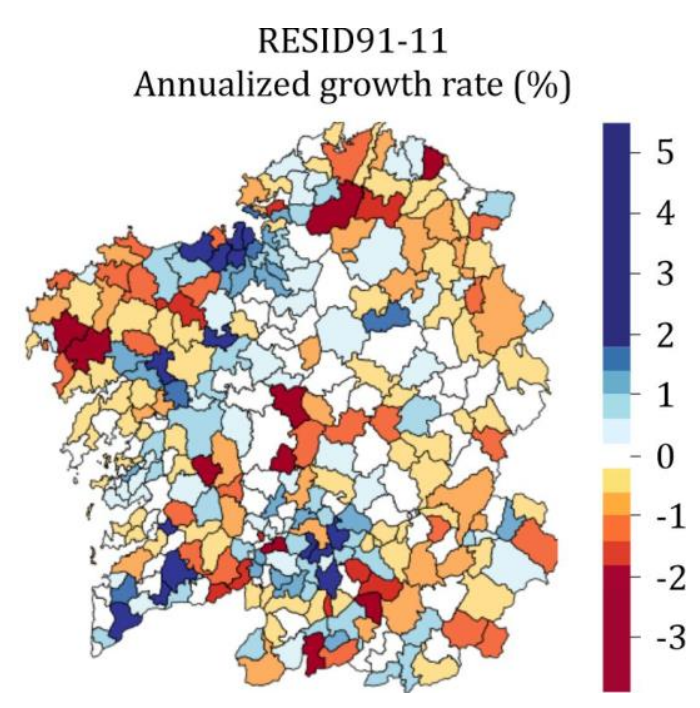

Figure 3. Residuals of the demographic drag by municipalities. Source: Own elaboration.

Figure 3 provides an alternative view of the population dynamics in Galicia, where the depopulation process not inherited from the past is not widespread. The areas with a better performance, clearly improving their relative dynamics in the last two decades, are primarily concentrated in the vicinity of the cities and along the Eixo Atlántico, as well as in the outskirts of the inner city of Ourense. In addition, we may talk of a central Galicia with stable population levels, once the drift from the past is removed -though with some negative cases, related to orography.

Indeed, negative performance (i.e., an accelerated depopulation beyond the dragging effect from the past) seems to be linked to adverse orography. Thus, much of the Galician municipalities with negative residuals are in the line formed by the mountain ranges of Xistral, Ancares, Courel, Macizo Central, and Trevinca which extends along the Northern and Eastern third of the region. Similar results are observed in the Dorsal Central, another mountainous area that goes from North to South in the centre of Galicia. Finally, we may observe two coastal areas with bad performance. The first one to the North -corresponding to the municipalities of Ferrol, Fene, As Pontes and Ortigueira -is the result of the restructuring of the shipping industry located there in the 1980s. The second one, and the worst case in terms of relative decline compared to previous trends, is a coastal area to the West of the Eixo Atlántico, known as the Costa da Morte. This is a rural area where the decline would correspond to late employment reductions in agrarian and fishery sectors.

\footnotetext{
3 The 315 municipalities of Galicia are grouped in 53 counties ("comarcas"), a unit officially recognized of closely related municipalities, but without administrative effects.
} 


\section{The factors behind the recovery of rural areas in socioeconomic decline}

We seek to investigate several interconnected causes analysed without hierarchical causality, trying to capture the complexity of processes and aspects that influence the dynamics of rural areas, in a way that linear and hierarchical approaches should be avoided (Salvati \& Carlucci, 2016). We focus on the rural municipalities, according to the characterization by the Galician Statistics Institute (IGE) following DEGURBA standards (Eurostat, 2011) -recall Figure 1 above-4. We trace which factors, and particularly those related to business activities and quality of life, are associated with the recovery or improvement of rural areas.

\subsection{Variables and data}

Most variables come from data provided by official statistical sources -the Spanish Statistics Institute (INE) and the IGE, as well as some agencies from the Spanish and Galician ministries-, while business financial data was obtained from SABI -Bureau van Dijk database. The area under study is the whole population of 315 Galician municipalities up to 2011, of which the 264 classified as rural, according to IGE, are the main research target. The period considered is from 1991 to 2011, to observe, in particular, how the socio-economic situation of the municipalities in early 1990s implies a path dependence on their population growth throughout the two decades under analysis. We will add some insights on the dichotomy 'entrepreneurship vs. quality of life'. Here, due to lack of data available, we will observe the consequences at period end (year 2011) of a positive demographic performance. Hence, any causal interpretation of the impact of entrepreneurship or quality of life factors should be avoided. However, this analysis might offer some insights on the ability of municipalities to reverse path dependence.

The variables were classified within 10 domains, for a total of 50 indicators. Table A3 in the SM provides all indicators, including their description or estimation procedure, and data sources. The first domain includes the population growth variables DEPOP $_{91-11}$ and RESID $_{91-11}$, the interpretation of which is the main object of study. These, together with EMIG $_{50-91}$ (now excluded in this analysis) and the indicators in the second domain -demographic structure- were already described in Section 2. To them we add a series of socio-economic domains that might be potential sources of population growth for rural areas beyond their demographic drag. These include territorial variables such as infrastructures and remoteness (e.g., Smailes et al., 2002), the stock of human capital, including education and labour market (Salvati and Carlucci, 2016), economic diversification (e.g., Marsden \& Sonnino, 2008), tprofitability and shifts in the location of business activities (Stephens et al., 2013), and quality of life indicators -including personal income, access to public services (Sánchez-Zamora et al., 2014) and amenities (Figueiredo, 2009), and trends of urban lifestyles in rural areas (Eliasson et al., 2015).

In what follows, we summarize the indicators we used for these eight additional domains. Thus, geographical and population variables are included in four domains. First, for each municipality, we consider geographical variables such as the population of the county capital in year $1991(x 0)$ and its natural logarithm $\left(\log _{-} x 0\right)$, the distances in kilometres to the county capital $(x 2)$, to the closest city $(x 3)$ and to the Eixo Atlántico ( $x 4)$, as well as those distances in minutes by road $(x 2 b, x 3 b$ and $x 4 b$, respectively). These data consider Galicia an island:, the effects that other growth poles in North Portugal and the rest of Spain could have on Galician border areas are not observed. Second, to approach the characteristics of each municipality's population up to 1991 we take the population density (dens91), percentage of foreign residents (forei), percentage of residents that were born in the municipality (born), percentage of residents that were born outside Galicia (abroad) -these two as a

\footnotetext{
4 The IGE recently provided an updated classification (IGE, 2016) using the same methodology. The number of rural municipalities would now be reduced to 240, of which only two were considered to be intermediate in 2011 .
} 
proxy for the ability of each municipality to attract people from other territories- and the percentage of men (men) to total population. Third, we consider three indicators for the education level up up 1991: namely, the percentage of illiterate population or literate with no formal degree $(e 1)$, the percentage of population with secondary education $(e 2)$ and with tertiary level education $(e 3)$ and fourth, three indicators of the labour market, namely, the activity rate (active), employment rate (emplo) and unemployment rate (unemp).

A seventh domain seeks to include some quality of life indicators. We had to use a variety of indeces in different instances, but we still had problems obtaining statistics that are either available for all municipalities, referring to the period of study, and representative of such instances. For personal income we use the disposable income per capita (income96) in 1996 (the oldest data available), representative of the structural conditions of each municipality at the beginning of the period of analysis. For other indicators we had to use a series of proxies, all of them referring to the end of the period (2011). The percentage of residents with access to integrated services digital network (ISDN) is used as a proxy of trends in urban lifestyles as well as for access to public services, the latter together with the number of places in social services centres for older people, disabilities, minors, family, immigrants and community services (social). In addition, we use the number of beds in hotels, rural houses and campsites per 1,000 residents (tour) as a proxy for the existence of amenities, and the ratio of work accidents with registered leave per 1,000 inhabitants (work) as an indicator of quality of life at work. Finally, the disposable income per capita (income09) at the end of the period of analysis -2009, in this case due to lack of official data for 2011- is used again in order to have data consistent with the other proxy indicators for quality of life.

Finally, in terms of economic activity and entrepreneurship we obtained indicators in the three last domains. The first one (the eighth in the overall list) is the sectoral structure of employment in 1991, to be interpreted together with other variables that account for the structural factors of the municipality at the beginning of the period of analysis. This domain includes the percentage of total employment in the following sectors: farming (emp1), fishing (emp2), industry (emp3), construction (emp4), and services (emp5). The two other domains use more recent data for the end of the period of analysis, again, due to lack of data in some instances- trying to capture the dimension and performance of business activities in relation to the population of each municipality. Thus, the ninth domain summarizes the business financial results of any firms in each municipality with complete data in the SABI database over the period 2001-2010. We have considered four ratios -total sales revenues (b1r), total assets $(b 2 r)$, total equity $(b 3 r)$, and earnings before taxes $(b 4 r)$ - that estimate the sum of these accounting measures for all firms divided by the population of the municipality. In addition, we obtained the firms' average return on assets (b5) and the ratio of all the firms' employees to the municipality's population $(b 6 r)$. Since the SABI database provides only a sample of all firms registered in a municipality, we considered a tenth and last domain where we use data from IGE to obtain four indicators of business density. The main contribution made by including these variables is to take into account the role of selfemployment ${ }^{5}$. These are the number of firms per 1,000 inhabitants $(b 7 r)$, and the equivalent measures for the firms in industrial sector (b7ir), construction $(b 7 c r)$ and services sector $(b 7 s r)$-all of them referring to 2010 .

\subsection{Descriptive statistics}

Table 1 provides the main descriptive statistics for the indicators previously explained. For each indicator, the estimations refer to the 264 rural municipalities under study 1.09 million inhabitants in 2011), and they are compared below with the equivalent results for the 51 urban and intermediate municipalities (1.69 million inhabitants in 2011).

5 IGE has more than 120,000 firms registered in rural and intermediate municipalities in year 2011, of which 74,000 are self-employed workers. PLCs, Ltds and cooperatives amount to 37,500 companies, and SABI lists 8,800. 
Table 1. Descriptive statistics

\begin{tabular}{|c|c|c|c|c|c|c|c|c|c|c|}
\hline & & $\mathrm{N}$ & Mean & Std. Dev. & Min & p25 & Median & p75 & Max & Range \\
\hline \multirow[t]{2}{*}{ EMIG.5091 } & rural & 264 & $-1.1460 \%$ & $.8454 \%$ & $-3.5982 \%$ & $-1.7538 \%$ & $-1.1673 \%$ & $-.5511 \%$ & $2.2381 \%$ & $5.8362 \%$ \\
\hline & urban-intermed & 51 & $.7343 \%$ & $.6356 \%$ & $-.8743 \%$ & $.2726 \%$ & $.6751 \%$ & $1.1562 \%$ & $2.2374 \%$ & $3.1117 \%$ \\
\hline \multirow[t]{2}{*}{ DEPOP.9111 } & rural & 264 & $-1.1372 \%$ & $1.2458 \%$ & $-3.8721 \%$ & $-1.9460 \%$ & $-1.3162 \%$ & $-.4811 \%$ & $5.4812 \%$ & $9.3534 \%$ \\
\hline & urban-intermed & 51 & $.6621 \%$ & $1.0072 \%$ & $-.9978 \%$ & $.1378 \%$ & $.5148 \%$ & $1.0858 \%$ & $3.5477 \%$ & $4.5455 \%$ \\
\hline \multirow[t]{2}{*}{ RESID.9111 } & rural & 264 & $-.0374 \%$ & $1.0455 \%$ & $-3.8514 \%$ & $-.5934 \%$ & $-.0923 \%$ & $.4654 \%$ & $5.6404 \%$ & $9.4918 \%$ \\
\hline & urban-intermed & 51 & $.1936 \%$ & $1.0735 \%$ & $-2.4330 \%$ & $-.3296 \%$ & $.0712 \%$ & $.5652 \%$ & $2.6843 \%$ & $5.1173 \%$ \\
\hline \multirow[t]{2}{*}{ d1 } & rural & 264 & 43.8 & 4.1 & 33.8 & 40.7 & 44.6 & 46.6 & 53.7 & 19.9 \\
\hline & urban-intermed & 51 & 36.8 & 2.4 & 32.9 & 34.9 & 36.2 & 37.9 & 43.2 & 10.3 \\
\hline \multirow[t]{2}{*}{$\mathrm{d} 2$} & rural & 264 & 21.3 & 4.6 & 10.8 & 18.1 & 20.5 & 24.6 & 33.4 & 22.7 \\
\hline & urban-intermed & 51 & 28.9 & 3.1 & 21.1 & 26.4 & 29.2 & 31.4 & 34.8 & 13.7 \\
\hline \multirow[t]{2}{*}{ d3 } & rural & 264 & 23.4 & 6.0 & 9.9 & 18.8 & 24.4 & 27.7 & 38.6 & 28.7 \\
\hline & urban-intermed & 51 & 13.6 & 2.9 & 9.4 & 11.3 & 12.5 & 14.9 & 23.0 & 13.6 \\
\hline \multirow[t]{2}{*}{ d4 } & rural & 264 & 121.1 & 56.8 & 30.7 & 76.7 & 121.8 & 149.4 & 351.3 & 320.5 \\
\hline & urban-intermed & 51 & 48.5 & 16.5 & 27.2 & 36.4 & 43.5 & 52.4 & 109.3 & 82.2 \\
\hline \multirow{2}{*}{ d5 } & rural & 264 & 9.7 & 1.8 & 3.4 & 8.5 & 9.6 & 10.6 & 15.5 & 12.0 \\
\hline & urban-intermed & 51 & 9.0 & 1.5 & 6.5 & 8.1 & 8.8 & 10.0 & 12.1 & 5.6 \\
\hline \multirow[t]{2}{*}{ d6 } & rural & 264 & 62.5 & 8.6 & 41.1 & 56.2 & 61.1 & 68.3 & 90.0 & 49.0 \\
\hline & urban-intermed & 51 & 51.2 & 3.9 & 41.7 & 49.5 & 50.9 & 52.5 & 61.6 & 19.9 \\
\hline \multirow[t]{2}{*}{ d7 } & rural & 264 & 104.8 & 21.4 & 64.2 & 88.1 & 103.7 & 117.9 & 183.0 & 118.8 \\
\hline & urban-intermed & 51 & 75.2 & 9.9 & 59.3 & 67.0 & 72.1 & 82.9 & 97.5 & 38.2 \\
\hline \multirow[t]{2}{*}{ d8 } & rural & 264 & 120.5 & 45.1 & 41.2 & 84.7 & 116.4 & 148.2 & 300.0 & 258.8 \\
\hline & urban-intermed & 51 & 60.1 & 15.1 & 41.4 & 49.4 & 57.2 & 68.2 & 117.2 & 75.8 \\
\hline \multirow[t]{2}{*}{$\mathrm{x} 0$} & rural & 264 & 26,832 & 44,999 & 1,874 & 7,016 & 11,134 & 20,318 & 276,109 & 274,235 \\
\hline & urban-intermed & 51 & 100,210 & 105,086 & 7,109 & 15,242 & 32,170 & 246,953 & 276,109 & 269,000 \\
\hline \multirow[t]{2}{*}{$\log _{-} x 0$} & rural & 264 & 9.51 & 1.04 & 7.54 & 8.86 & 9.32 & 9.92 & 12.53 & 4.99 \\
\hline & urban-intermed & 51 & 10.85 & 1.24 & 8.87 & 9.63 & 10.38 & 12.42 & 12.53 & 3.66 \\
\hline x2 & rural & 264 & 14.9 & 9.3 & 0.0 & 8.6 & 14.8 & 20.9 & 49.6 & 49.6 \\
\hline & urban-intermed & 51 & 9.5 & 10.2 & 0.0 & 0.0 & 7.2 & 18.3 & 38.9 & 36.9 \\
\hline$x 2 b$ & rural & 264 & 17.4 & 10.1 & 0.0 & 11.0 & 17.0 & 24.0 & 50.0 & 50.0 \\
\hline & urban-intermed & 51 & 11.2 & 10.9 & 0.0 & 0.0 & 12.0 & 19.0 & 38.0 & 38.0 \\
\hline x3 & rural & 264 & 45.4 & 25.3 & 5.1 & 26.5 & 40.9 & 55.6 & 143.0 & 137.9 \\
\hline & urban-intermed & 51 & 30.3 & 27.4 & 0.0 & 11.3 & 23.6 & 42.3 & 113.0 & 113.0 \\
\hline $\mathrm{x} 3 \mathrm{~b}$ & rural & 264 & 41.6 & 19.1 & 10.0 & 28.0 & 37.0 & 51.0 & 135.0 & 125.0 \\
\hline & urban-intermed & 51 & 27.8 & 21.7 & 0.0 & 15.0 & 25.0 & 36.0 & 90.0 & 90.0 \\
\hline $\mathrm{x} 4$ & rural & 264 & 89.2 & 49.8 & 11.2 & 48.0 & 80.0 & 127.0 & 245.0 & 233.8 \\
\hline & urban-intermed & 51 & 51.8 & 44.2 & 4.4 & 20.4 & 42.3 & 71.3 & 219.0 & 214.6 \\
\hline $\mathrm{x} 4 \mathrm{~b}$ & rural & 264 & 62.9 & 29.5 & 13.0 & 40.0 & 60.5 & 81.8 & 175.0 & 162.0 \\
\hline & urban-intermed & 51 & 38.5 & 26.2 & 7.0 & 19.0 & 32.0 & 51.0 & 126.0 & 119.0 \\
\hline dens91 & rural & 264 & 61.2 & 65.4 & 4.7 & 26.8 & 40.7 & 74.4 & 692.9 & 688.2 \\
\hline & urban-intermed & 51 & 552.8 & 941.0 & 53.5 & 223.2 & 366.4 & 520.9 & 6567.9 & 6514.4 \\
\hline forei & rural & 264 & $0.69 \%$ & $1.31 \%$ & $0.00 \%$ & $0.17 \%$ & $0.38 \%$ & $0.72 \%$ & $15.41 \%$ & $15.41 \%$ \\
\hline & urban-intermed & 51 & $0.70 \%$ & $0.56 \%$ & $0.07 \%$ & $0.37 \%$ & $0.55 \%$ & $0.87 \%$ & $3.37 \%$ & $3.30 \%$ \\
\hline born & rural & 264 & $78.7 \%$ & $8.6 \%$ & $38.3 \%$ & $75.4 \%$ & $80.0 \%$ & $84.2 \%$ & $96.5 \%$ & $58.2 \%$ \\
\hline & urban-intermed & 51 & $64.0 \%$ & $14.4 \%$ & $30.5 \%$ & $54.7 \%$ & $64.1 \%$ & $75.0 \%$ & $85.1 \%$ & $54.5 \%$ \\
\hline abroad & rural & 264 & $5.1 \%$ & $3.7 \%$ & $0.7 \%$ & $2.8 \%$ & $4.2 \%$ & $6.2 \%$ & $27.1 \%$ & $26.5 \%$ \\
\hline & urban-intermed & 51 & $6.5 \%$ & $3.5 \%$ & $1.7 \%$ & $3.4 \%$ & $5.6 \%$ & $8.5 \%$ & $17.0 \%$ & $15.3 \%$ \\
\hline men & rural & 264 & $48.9 \%$ & $1.7 \%$ & $43.9 \%$ & $48.0 \%$ & $48.9 \%$ & $49.8 \%$ & $55.2 \%$ & $11.3 \%$ \\
\hline & urban-intermed & 51 & $48.4 \%$ & $0.8 \%$ & $46.9 \%$ & $48.0 \%$ & $48.4 \%$ & $49.0 \%$ & $50.4 \%$ & $3.5 \%$ \\
\hline educ1 & rural & 264 & $43.5 \%$ & $13.6 \%$ & $5.9 \%$ & $34.8 \%$ & $44.7 \%$ & $54.6 \%$ & $77.1 \%$ & $71.2 \%$ \\
\hline & urban-intermed & 51 & $24.7 \%$ & $7.6 \%$ & $13.9 \%$ & $19.5 \%$ & $23.8 \%$ & $27.5 \%$ & $59.8 \%$ & $46.0 \%$ \\
\hline educ2 & rural & 264 & $18.3 \%$ & $3.7 \%$ & $8.1 \%$ & $15.7 \%$ & $18.1 \%$ & $20.6 \%$ & $32.7 \%$ & $24.6 \%$ \\
\hline & urban-intermed & 51 & $26.9 \%$ & $4.1 \%$ & $18.5 \%$ & $23.5 \%$ & $26.5 \%$ & $29.7 \%$ & $37.3 \%$ & $18.8 \%$ \\
\hline educ3 & rural & 264 & $2.0 \%$ & $1.0 \%$ & $0.1 \%$ & $1.2 \%$ & $1.8 \%$ & $2.3 \%$ & $7.2 \%$ & $7.1 \%$ \\
\hline & urban-intermed & 51 & $4.1 \%$ & $2.3 \%$ & $1.4 \%$ & $2.6 \%$ & $3.3 \%$ & $4.7 \%$ & $12.4 \%$ & $11.0 \%$ \\
\hline activ & rural & 264 & 47.5 & 7.6 & 31.1 & 43.0 & 46.4 & 51.2 & 91.3 & 60.2 \\
\hline & urban-intermed & 51 & 48.1 & 4.6 & 38.6 & 45.2 & 48.3 & 51.0 & 61.2 & 22.6 \\
\hline emplo & rural & 264 & 41.5 & 8.7 & 23.0 & 36.0 & 40.5 & 45.4 & 90.5 & 67.5 \\
\hline & urban-intermed & 51 & 39.2 & 4.6 & 28.7 & 36.9 & 39.7 & 42.2 & 52.6 & 23.9 \\
\hline unemp & rural & 264 & 13.0 & 6.2 & 1.0 & 8.7 & 12.4 & 16.6 & 34.7 & 33.7 \\
\hline & urban-intermed & 51 & 18.7 & 4.5 & 9.1 & 15.8 & 17.6 & 21.6 & 29.7 & 20.6 \\
\hline
\end{tabular}


Table 1 (continuation). Descriptive statistics

\begin{tabular}{|c|c|c|c|c|c|c|c|c|c|c|}
\hline & & $\mathrm{N}$ & Mean & Std. Dev. & Min & p25 & Median & p75 & Max & Range \\
\hline \multirow[t]{2}{*}{ income96 } & rural & 264 & 5,402 & 1,007 & 2,124 & 4,813 & 5,311 & 5,936 & 11,280 & 9,156 \\
\hline & urban-intermed & 51 & 6,726 & 965 & 4,890 & 6,012 & 6,501 & 7,424 & 9,104 & 4,214 \\
\hline \multirow[t]{2}{*}{ income09 } & rural & 264 & 12,199 & 1,864 & 7,589 & 10,812 & 12,187 & 13,492 & 18,859 & 11,271 \\
\hline & urban-intermed & 51 & 14,862 & 1,976 & 11,552 & 13,222 & 14,431 & 16,059 & 20,189 & 8,637 \\
\hline \multirow[t]{2}{*}{ ISDN } & rural & 264 & $39.14 \%$ & $38.57 \%$ & $0.00 \%$ & $0.00 \%$ & $28.07 \%$ & $79.99 \%$ & $100.00 \%$ & $100.00 \%$ \\
\hline & urban-intermed & 51 & $56.52 \%$ & $47.97 \%$ & $0.00 \%$ & $0.00 \%$ & $95.21 \%$ & $100.00 \%$ & $100.00 \%$ & $100.00 \%$ \\
\hline \multirow[t]{2}{*}{ social } & rural & 264 & 20.79 & 24.01 & 0.00 & 0.00 & 14.71 & 29.80 & 169.88 & 169.88 \\
\hline & urban-intermed & 51 & 24.62 & 12.30 & 0.00 & 17.14 & 22.46 & 31.06 & 62.19 & 62.19 \\
\hline \multirow{2}{*}{ tour } & rural & 264 & 0.05 & 0.09 & 0.00 & 0.01 & 0.02 & 0.06 & 0.82 & 0.82 \\
\hline & urban-intermed & 51 & 61.43 & 88.15 & 3.44 & 15,99 & 25.15 & 70.49 & 524.63 & 521.19 \\
\hline \multirow[t]{2}{*}{ work } & rural & 264 & 9.59 & 15.52 & 0.00 & 3.91 & 6.94 & 11.21 & 198.68 & 198.68 \\
\hline & urban-intermed & 51 & 19.71 & 13.25 & 3.80 & 11.26 & 17.31 & 23.26 & 81.70 & 77.91 \\
\hline \multirow[t]{2}{*}{ emp1 } & rural & 264 & $43.1 \%$ & $19.3 \%$ & $1.9 \%$ & $28.5 \%$ & $44.6 \%$ & $56.5 \%$ & $89.4 \%$ & $87.4 \%$ \\
\hline & urban-intermed & 51 & $6.9 \%$ & $6.6 \%$ & $1.0 \%$ & $2.9 \%$ & $5.2 \%$ & $8.2 \%$ & $37.5 \%$ & $36.6 \%$ \\
\hline \multirow[t]{2}{*}{ emp2 } & rural & 264 & $1.7 \%$ & $5.0 \%$ & $0.0 \%$ & $0.0 \%$ & $0.1 \%$ & $0.5 \%$ & $37.1 \%$ & $37.1 \%$ \\
\hline & urban-intermed & 51 & $8.9 \%$ & $11.2 \%$ & $0.0 \%$ & $0.4 \%$ & $3.2 \%$ & $14.1 \%$ & $43.4 \%$ & $43.4 \%$ \\
\hline \multirow[t]{2}{*}{ emp3 } & rural & 264 & $13.1 \%$ & $8.1 \%$ & $1.2 \%$ & $7.1 \%$ & $12.4 \%$ & $16.9 \%$ & $71.8 \%$ & $70.5 \%$ \\
\hline & urban-intermed & 51 & $23.4 \%$ & $9.5 \%$ & $11.1 \%$ & $15.4 \%$ & $22.1 \%$ & $28.0 \%$ & $51.2 \%$ & $40.1 \%$ \\
\hline \multirow[t]{2}{*}{ emp4 } & rural & 264 & $14.6 \%$ & $6.4 \%$ & $2.2 \%$ & $9.6 \%$ & $14.2 \%$ & $18.7 \%$ & $37.0 \%$ & $34.8 \%$ \\
\hline & urban-intermed & 51 & $13.6 \%$ & $3.6 \%$ & $6.9 \%$ & $10.8 \%$ & $13.2 \%$ & $16.1 \%$ & $22.0 \%$ & $15.0 \%$ \\
\hline \multirow[t]{2}{*}{ emp5 } & rural & 264 & $27.5 \%$ & $9.7 \%$ & $5.6 \%$ & $20.7 \%$ & $26.4 \%$ & $33.3 \%$ & $59.7 \%$ & $54.1 \%$ \\
\hline & urban-intermed & 51 & $47.2 \%$ & $11.2 \%$ & $28.3 \%$ & $39.4 \%$ & $45.1 \%$ & $52.2 \%$ & $71.9 \%$ & $43.6 \%$ \\
\hline \multirow[t]{2}{*}{ b1r } & rural & 264 & 7.48 & 21.82 & 0.00 & 1.01 & 3.23 & 6.71 & 278.49 & 278.49 \\
\hline & intermediate & 51 & 16.47 & 17.16 & 0.21 & 5.02 & 10.43 & 19.03 & 71.92 & 71.71 \\
\hline \multirow[t]{2}{*}{$\mathrm{b} 2 \mathrm{r}$} & rural & 264 & 7.94 & 23.28 & 0.00 & 0.82 & 2.65 & 5.70 & 225.89 & 225.89 \\
\hline & intermediate & 51 & 14.49 & 15.41 & 0.11 & 4.38 & 9.65 & 17.40 & 72.30 & 72.19 \\
\hline \multirow[t]{2}{*}{ b3r } & rural & 264 & 2.82 & 9.82 & -0.05 & 0.20 & 0.85 & 2.01 & 117.75 & 117.81 \\
\hline & intermediate & 51 & 4.65 & 4.99 & 0.03 & 1.45 & 2.77 & 5.24 & 26.10 & 26.06 \\
\hline \multirow[t]{2}{*}{$\mathrm{b} 4 \mathrm{r}$} & rural & 264 & 0.41 & 2.66 & -1.25 & 0.00 & 0.05 & 0.17 & 40.39 & 41.64 \\
\hline & intermediate & 51 & 0.53 & 0.66 & 0.00 & 0.12 & 0.28 & 0.55 & 2.81 & 2.81 \\
\hline \multirow[t]{2}{*}{ b5 } & rural & 264 & 1.41 & 3.57 & -35.03 & 0.02 & 1.82 & 3.04 & 8.37 & 43.40 \\
\hline & intermediate & 51 & -4.44 & 35.95 & -236.19 & 0.06 & 1.51 & 2.80 & 5.43 & 241.61 \\
\hline \multirow[t]{2}{*}{ b6r } & rural & 264 & 49.82 & 111.76 & 0.00 & 10.02 & 26.58 & 57.87 & $1,092.13$ & $1,092.13$ \\
\hline & intermediate & 51 & 97.45 & 99.48 & 4.07 & 43.70 & 74.36 & 103.15 & 497.31 & 493.24 \\
\hline \multirow[t]{2}{*}{ b7r } & rural & 264 & 57.97 & 17.05 & 21.06 & 46.48 & 55.96 & 68.42 & 144.17 & 123.10 \\
\hline & intermediate & 51 & 71.42 & 13.94 & 44.77 & 61.42 & 70.60 & 80.97 & 112.37 & 67.60 \\
\hline \multirow[t]{2}{*}{ b7ir } & rural & 264 & 6.81 & 3.98 & 0.00 & 4.24 & 6.09 & 8.34 & 30.71 & 30.71 \\
\hline & intermediate & 51 & 6.11 & 3.27 & 2.60 & 3.75 & 5.11 & 7.32 & 16.14 & 13.55 \\
\hline \multirow[t]{2}{*}{$\mathrm{b} 7 \mathrm{cr}$} & rural & 264 & 13.07 & 4.48 & 0.00 & 10.02 & 12.96 & 15.68 & 26.04 & 26.04 \\
\hline & intermediate & 51 & 13.00 & 4.03 & 6.03 & 10.03 & 12.18 & 15.36 & 24.66 & 18.63 \\
\hline \multirow[t]{2}{*}{ b7sr } & rural & 264 & 38.08 & 13.15 & 9.03 & 28.35 & 37.18 & 45.45 & 89.14 & 80.12 \\
\hline & intermediate & 51 & 52.32 & 9.17 & 35.27 & 46.10 & 52.56 & 57.59 & 72.62 & 37.35 \\
\hline
\end{tabular}

Source: Own elaboration.

The urban-rural split in Galicia is easy to observe following these standards. Rural municipalities, by 1991 had a density of 61 inhabitants per $\mathrm{km}^{2}$ of a mean age of 44; urban areas had a density of 553 inhabs $/ \mathrm{km}^{2}$ and 37 years old. On average, rural municipalities lost $1.15 \%$ of their population annually from 1950 to 1991, and they kept losing population at that pace from 1991 to 2011. However, urban areas increased population every year by about $0.7 \%$ in both periods. Most of this separate performance comes from historic migrations: in terms of residuals of the demographic drag, rural municipalities are barely losing $0.04 \%$ annually on average, but intra-rural differences appear to be relevant -with a standard deviation of more than $1.0 \%$.

A look at the different domains considered in the analysis offers more insights about the urban-rural divide. Rural (urban) municipalities are under the influence of county capitals with27,000 $(100,000)$ 
inhabitants, 90 (50) kilometres away from the Eixo Atlántico (the main urban axis of Galicia). The average disposable income was 5,400 euros in 1996 -compared to 6,700 in urban areas- and increased to 12,200 euros $(14,900$ euros in urban areas) in 2009 , with high intra-rural differences. The percentage of illiterate population or with no formal degree in rural areas doubled that of urban municipalities, and the average access to internet services was only $28.1 \%$, versus $95.2 \%$ in urban areas. Finally, $45 \%$ of the employment in rural areas up to 1991 came from the farming and fishing sectors, for only a 7\% in urban and intermediate municipalities, while the employment in the services sector was $27.5 \%$ and $47.2 \%$, respectively. Similar negative differences for rural areas are observed in terms of business size (total sales, assets, revenues and equity per 1,000 inhabitants) and business density, especially in the services sector.

\subsection{Multivariate statistical analysis}

Focusing on Galician rural areas according to DEGURBA standards -identified as rural (high, interm., or low) in the RHS of Figure 1, which makes 264 municipalities-, we perform a principal component analysis (PCA) for all aforementioned variables The purpose of a PCA is to explain the variancecovariance structure of this set of variables, by creating new uncorrelated variables from linear combinations of the original ones. This simplifies the analysis, since only few components are now required to maintain much of the original information, while it facilitates the interpretation of the relations among the original variables in a way it would not be obvious with a direct observation (Johnson \& Wichern, 2014).

We use the Keiser-Meyer-Olkin (KMO) measure of sampling adequacy, to test whether the partial correlations among variables are small, and Bartlett's test of sphericity, which tests whether the correlation matrix is an identity matrix. We obtain a value 0.698 for the KMO and a p-value less than 0.05 for the Bartlett's test, which confirms the sample is adequate.

We considered 8 significant components, which account for a cumulated variance higher than $70 \%$. Notwithstanding, the main justification for this choice is the theoretical interpretability of the results see below. We then performed a varimax rotation to the components obtained, ${ }^{6}$ in order to get each variable associated with higher loads to a single component. For robustness, results for 6 to 10 components, as well as for none rotation, promax, cluster and quartimax rotations for 8 components, were also obtained - the complete results are available in Table A4 in the SM.

Results of the PCA carried out on the matrix composed of the 50 indicators for the 264 Galician rural municipalities are summarized in Table 2 , with loadings smaller than $|0.2|$ omitted for clarity. Loadings are the coefficients of each variable in the linear function of a specific component, measuring the importance of such variables in the component. Communality (h2) in factorial analysis represents the part of the variance of a variable that contributes to the formation of the components, and uniqueness (u2) the part that represents its specific behaviour.

Loadings $>|0.6|$ were used to determine the domains that are associated with each component. This way, the results obtained justify, from a theoretical perspective, the number of significant components and rotation techniques used. Indeed, the first rotated component (RC1) is clearly associated to the domain 'demographic structure' (which extracts 18\% of total variance) and RC2 to the domain 'business financial results' (12\% of total variance), both with loadings $>|0.9|$ for most indicators. In addition, RC5 and RC3 are also strongly identified with the distance to the main urban areas (domain 'geographic variables') and employment rates (domain 'labour market'). The last three rotated components, RC6 to RC8, which extract $14 \%$ of total variance altogether, have significant loadings higher than $|0.6|$ for most indicators in the domains 'geographic variables' (population of the county capital and distance to it), population (foreign people, born in the municipality and outside Galicia) and business density.

\footnotetext{
${ }^{6}$ For such purpose, we used the command principal in the package psych of the R statistical suite (Revelle, 2017).
} 
Table 2. Principal component analysis (PCA) factor loadings

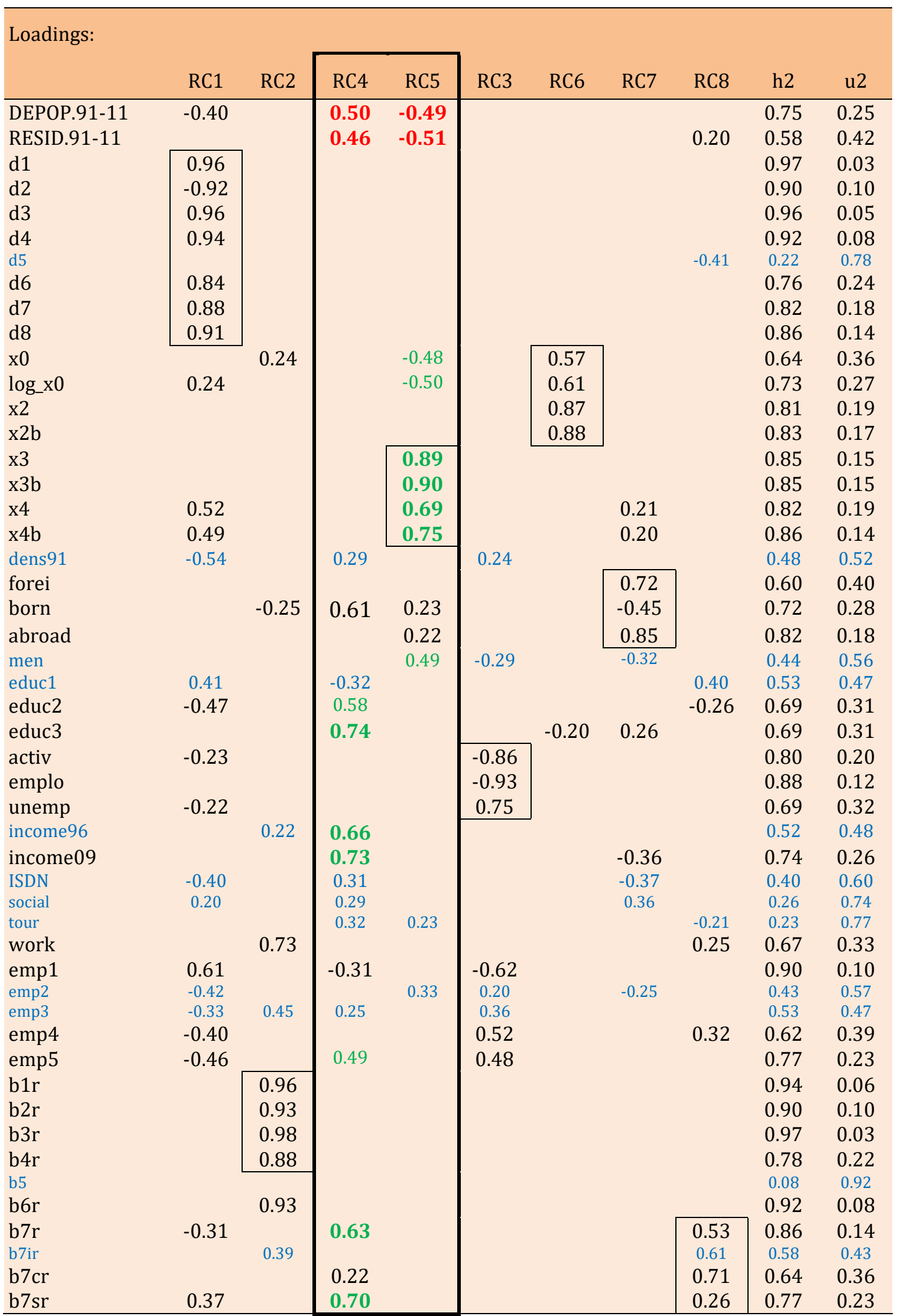


Table 2 (continuation). Principal component analysis (PCA) factor loadings

\begin{tabular}{lllllllll}
\hline & RC1 & RC2 & RC4 & RC5 & RC3 & RC6 & RC7 & RC8 \\
\hline SS loadings & 9.12 & 5.73 & 4.79 & 4.52 & 3.65 & 2.48 & 2.48 & 2.17 \\
Proportion Var & 0.18 & 0.12 & 0.10 & 0.09 & 0.07 & 0.05 & 0.05 & 0.04 \\
Cumulative VAR & 0.18 & 0.30 & 0.39 & 0.48 & 0.56 & 0.61 & 0.66 & 0.70 \\
\hline
\end{tabular}

Notes: The order of the rotated components (RC) changed after the rotation. Loadings $<|0,2|$ were omitted for clarity. Proportion Var indicates the variance extracted by each component and $\mathrm{u} 2$ the uniqueness of each variable. Variables with a high uniqueness ( $\mathrm{u} 2>0.4$ ) were marked with the colour off. For better interpretation, the RC with the highest loads for DEPOP 91 11 and RESID $91-11$ was highlighted with the thickest rectangles, while thinner boxes indicate the relevant domains associated with each component. Source. Own elaboration.

The perfect match of seven domains with seven components validates our choice and explains $60 \%$ of total variance. A last component, RC4, the third in terms of extracted total variance for an additional $10 \%$, does not match a specific domain. However, it is going to offer the most interesting results to our research as it relates the population growth of rural areas to specific indicators in the domains of human capital, quality of life, and business density. Indeed, three domains of indicators have no direct association with a component of their own. The first case, 'quality of life', includes indicators with a high uniqueness and loadings diffused across components. It is fair to think that this result might be related with the heterogeneity of indicators used in this domain and the different sources of data. The other two, human capital (measured as the education level) and sectoral structure of employment, are structural conditions of the rural areas in 1991 that basically load over two components (related to the demographic structure and RC4 in the first case, and demographic structure and labour market the second).

\subsection{Interpretation of PCA results: the factors behind rural recovery}

The use of a high number of components, the fact that most indicators have a low uniqueness and the clear correspondence of seven domains to seven components with very high loadings, make any relationships outside those correspondences infrequent, but meaningful. We therefore consider loadings $>|0.6|$ to be relevant, and $>|0.3|$ deserve mention. Interpreted in this way, some results make sense: First, a negative population growth (DEPOP ${ }_{91-11}$ ) loads to component RC1, associated to demographic indicators at the beginning of the period, such as a higher mean age and a lower percentage of young people, as well as to municipalities of a lower density in 1991 (dens91), far away from the Eixo Atlántico $(x 4$ and $x 4 b$ ), and a high percentage of agricultural employment (emp1). However, none of these have a relation to RESID ${ }_{91-11}$. Beyond that, more work accidents are related to a denser business network and more employees per 1,000 inhabitants, and higher activity rates and lower unemployment rates are positively related to the employment in the farming sector.

Notwithstanding, it is the analysis of components RC4 and RC5 that offers more insights. The loadings of population growth and residuals beyond the drag are significant in these two domains, so any related indicators will be interpreted as factors behind a demographic recovery of rural areas - highlighted with the thickest rectangles in Table 2. We may distinguish factors in two areas. First, a territorial interpretation, a greater distance to the main urban areas and a smaller size of the county capital are related to negative population growth in absolute terms as well as after the dragging effect of past migration is removed. This result would be in line with the literature on agglomeration economies (Artz, Cho, Guo, Kim, Orazem \& Yu, 2015).

Additionally, a socio-economic interpretation, certain structural conditions in 1991 such as a higher ratio of university graduates, a higher disposable income, and fewer residents born in the same municipality are positively related to population recovery in recent decades. Moreover, a positive demographic performance from 1991 to 2011 is also related to certain quality of life indicators and business density at the end of that period, such as higher disposable income and the density of 
companies and freelancers in the services sector. Other noteworthy factors, with loadings $>|0.3|$, are higher ratio of employment in the services sector in 1991, as well as quality of life indicators in 2011 such as the access to ISDN services, places in social services centres, and the number of beds in hotels and campsites. Two other results are related to the education level (illiterate population and secondary education), but both are correlated with the demographic structure in component RC1, since younger municipalities are expected to have more people with a secondary education and fewer with no studies.

Therefore, the debate is still open regarding the dichotomy "fostering entrepreneurship in rural areas versus ensuring higher quality of life standards for residents there". On one hand, there is a clear result in favour of a denser business network in the tertiary sector -particularly in the form of self-employment- as a consequence, but we found no evidence on business financial results. On the other, there is a positive impact of having more university graduates and higher disposable income, but quality of life indicators such as proxies for the access to public services and the presence of amenities only offer weak correlations at period end. All these results are robust to alternative rotation techniques -see Table A4 in the SM. Thus, results are qualitatively similar for all methods considered, and they are quantitatively even more important with a cluster rotation (in particular, higher loadings by tertiary education level, distance to urban areas, and business density in the services sector).

\section{Conclusions}

The diversity and complexity of socio-economic phenomena that influence the dynamics of rural areas today, and to understand the context where demographic and entrepreneurial vitality emerges, requires the use of a wide range of variables and diverse statistical techniques, avoiding linear and hierarchical approaches. The article contributes to a recent line of research in Spain, such as Collantes, Pinilla, Sáez \& Silvestre (2014), who analyse the impact of immigration to rural areas as a potential solution to depopulation, and Eguía \& Aldaz (2019), who analyse the relationship between weak demographics and weak economics at the local level in the Basque Country.

In this article we have focused on the classic dichotomy of what should come first to maintain the vitality of rural areas: fostering entrepreneurship and the competitiveness of these territories, versus ensuring higher quality of life standards to attract residents, tourists and retirees. Focusing on Galicia (Spain) as a case study of a region in demographic decline, we performed a multivariate statistical analysis to observe which factors -in domains territorial, economic diversification, access to public services, human capital, business density and financial results- are related to a positive demographic performance after the negative effect caused by migration from rural areas in the past is removed.

We obtain mixed results for the dichotomy 'entrepreneurship versus quality of life', but we contribute with some results. First, there is clear evidence of agglomeration economies, in terms of a shorter distance of rural areas to the main urban centre in Galicia, as well as having a populated village nearby. Second, there is a positive impact of a higher disposable income and a higher ratio of university graduates, and we obtain correspondence between rural recovery and the density of companies and freelancers in the services sector. These results lead to some open questions: maybe it is not the dichotomy entrepreneurship versus quality of life that matters, but investing in human capital? What comes first: having more university graduates and being able to retain them as residents in rural areas contributes to an environment where entrepreneurship is fostered in the services sector or is it the other way around? Does a family background with higher disposable income enable university graduates to be retained in rural areas, or promote entrepreneurship activities?

This and subsequent research should serve to help to design better targeted rural development public policies to boost the recovery of declining rural areas. The evidence of agglomeration economies of having a village nearby emphasizes the necessity to reinforce some demographic nodes in rural areas, and the rationality of concentrating the provision of services in fewer nodes of higher quality. Moreover, innovative commuting policies may also transform territorial patterns during periods of demographic stagnation (López-Iglesias, Peón \& Rodríguez-Álvarez, 2018). However, there is a limit to agglomeration 
economies, too. At different levels, different responses are required. To avoid territorial exclusion, improving information systems and telematics interconnection, creating mobile units for social and health assistance, and prioritizing prevention might be different alternatives (Fernández \& Peón, 2017). Finally, public policies in support of business activities should pay attention to the barriers they face, such as financial constraints, qualified personnel, and uneven market competition (Peón \& Martínez Filgueira, 2019).

The main limitation of our research, both in terms of interpreting the results obtained and to answer some of these open questions, comes from the lack of data for Galicia at the municipal level. Moreover, the results of the statistical analysis should not be interpreted in terms of causality, but of association or relationship among variables. Indeed, PCA is an exploratory analysis, and this is the reason why no ex-ante testable hypotheses were defined. However, the methodology and results obtained could serve as a starting point in future research analysis for this and other regions, in terms of choosing the appropriate variables to be included in the econometric models.

\section{Appendix 1. Supplementary material}

Table A1. Correlations between population change 1950-1991, demographic structure in 1991, and population change 1911-2011(*)

\begin{tabular}{ccccccccccc}
\hline & EMIG. 5091 & DEPOP.9111 & $\mathrm{d} 1$ & $\mathrm{~d} 2$ & $\mathrm{~d} 3$ & $\mathrm{~d} 4$ & $\mathrm{~d} 5$ & $\mathrm{~d} 6$ & $\mathrm{~d} 7$ & $\mathrm{~d} 8$ \\
\hline EMIG.5091 & 1.00 & 0.65 & -0.89 & 0.86 & -0.89 & -0.83 & -0.16 & -0.78 & -0.76 & -0.81 \\
DEPOP.9111 & 0.65 & 1.00 & -0.64 & 0.65 & -0.63 & -0.61 & -0.14 & -0.49 & -0.54 & -0.58 \\
d1 & -0.89 & -0.64 & 1.00 & -0.98 & 0.99 & 0.96 & 0.21 & 0.84 & 0.91 & 0.92 \\
d2 & 0.86 & 0.65 & -0.98 & 1.00 & -0.94 & -0.93 & -0.19 & -0.73 & -0.87 & -0.91 \\
d3 & -0.89 & -0.63 & 0.99 & -0.94 & 1.00 & 0.96 & 0.19 & 0.91 & 0.87 & 0.90 \\
d4 & -0.83 & -0.61 & 0.96 & -0.93 & 0.96 & 1.00 & 0.17 & 0.86 & 0.86 & 0.93 \\
d5 & -0.16 & -0.14 & 0.21 & -0.19 & 0.19 & 0.17 & 1.00 & 0.17 & 0.18 & 0.14 \\
d6 & -0.78 & -0.49 & 0.84 & -0.73 & 0.91 & 0.86 & 0.17 & 1.00 & 0.74 & 0.77 \\
d7 & -0.76 & -0.54 & 0.91 & -0.87 & 0.87 & 0.86 & 0.18 & 0.74 & 1.00 & 0.86 \\
d8 & -0.81 & -0.58 & 0.92 & -0.91 & 0.90 & 0.93 & 0.14 & 0.77 & 0.86 & 1.00 \\
\hline
\end{tabular}

Note: ${ }^{*}$ ) Variables are described in Table A3. Source: Own elaboration. Data: INE, Census 1950, 1991, 2011.

Table A2. Regressions DEPOP $91-11$ as a function of one or more regressors 1 regressor

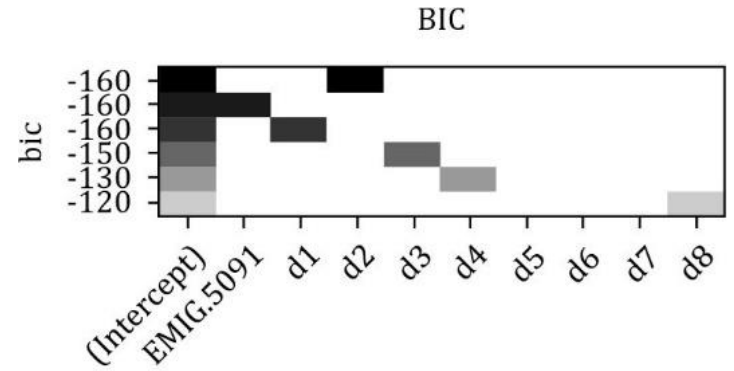

Adjusted R^2

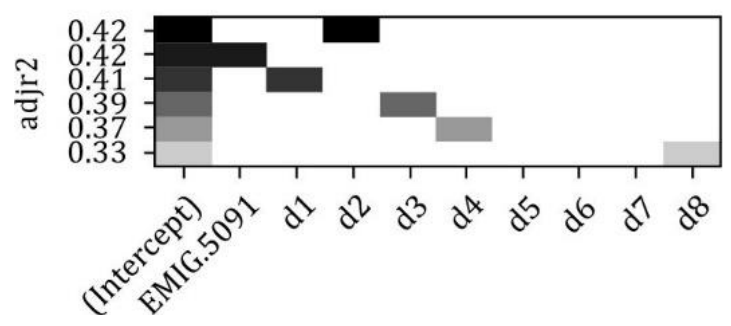

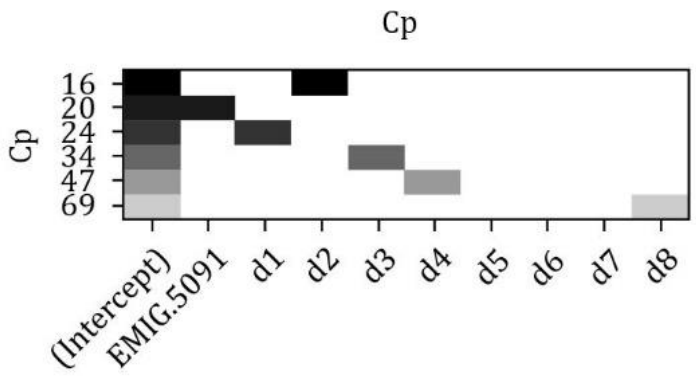

$\mathrm{R}^{\wedge} 2$

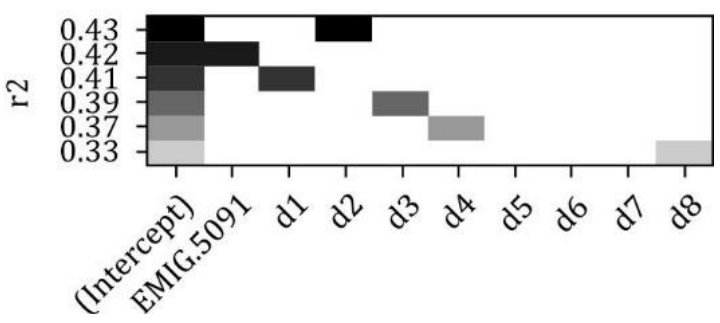


Table A2 (continuation). Regressions DEPOP91-11 as a function of one or more regressors

\section{2 regressors}
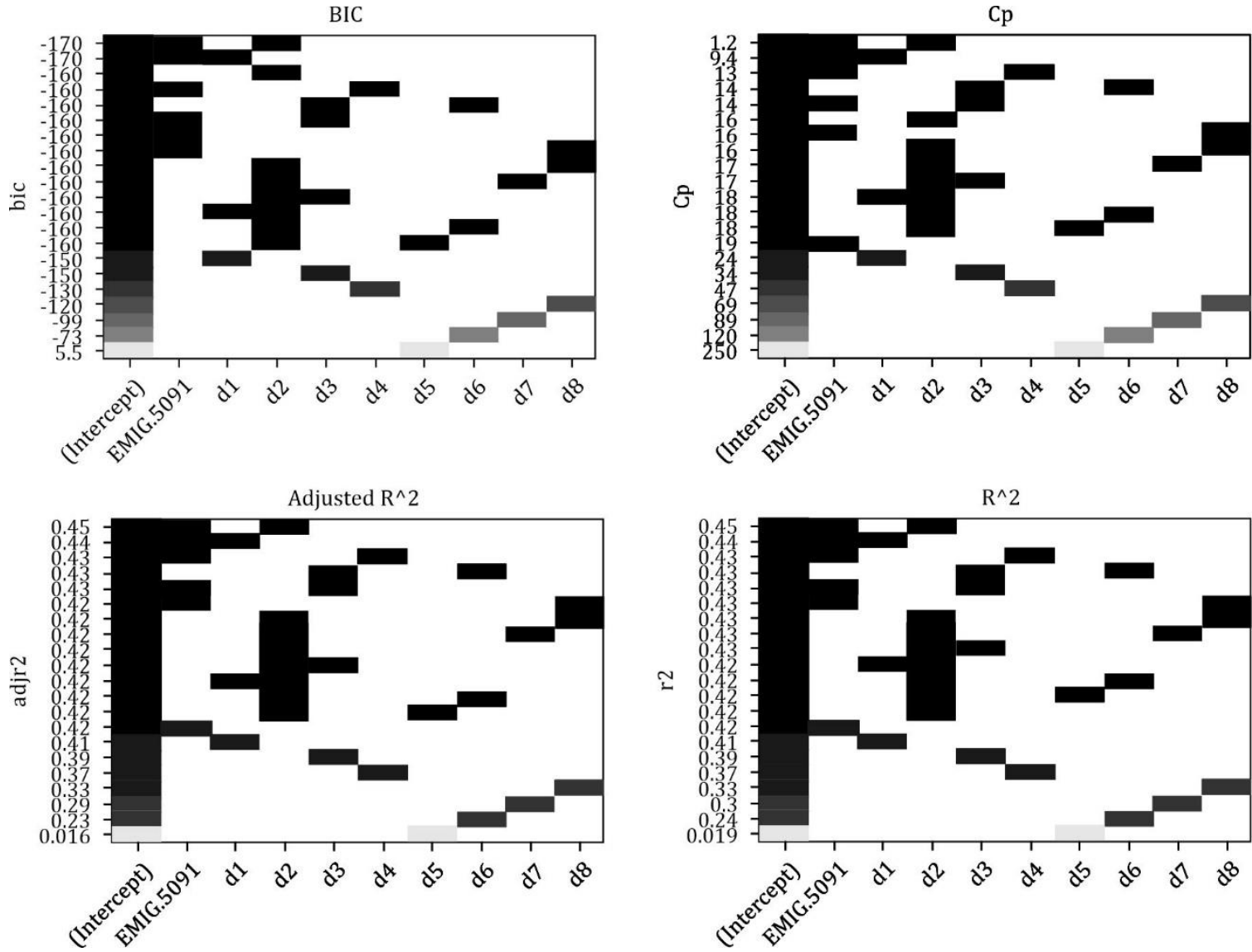

The $\mathrm{R}^{2}$ for regression $\mathrm{DEPOP}_{91-11}=\mathrm{f}\left(\mathrm{EMIG}_{50-91}\right)$ is almost identical to that with the best results - the regression that uses $\mathrm{d} 2$ as a regressor:

\begin{tabular}{|c|c|c|c|c|}
\hline & Estimate & Std. Error & t value & $\operatorname{Pr}(>|\mathrm{t}|)$ \\
\hline (Intercept) & -0.14373 & 0.07558 & -1.902 & 0.0581. \\
\hline EMIG.50-91 & 0.83423 & 0.05558 & 15.009 & $<2 \mathrm{e}-16^{* * *}$ \\
\hline
\end{tabular}

Signif. codes: 0 (***) $0.001^{\text {(**) }} 0.01^{\text {(*) }} 0.05$ '? $0.1^{\prime \prime \prime} 1$

Residual standard error: 1.053 on 313 degrees of freedom

Multiple R-squared: 0.4185, Adjusted R-squared: 0.4166

F-statistic: 225.3 on 1 and 313 DF, p-value: $<2.2 \mathrm{e}-16$

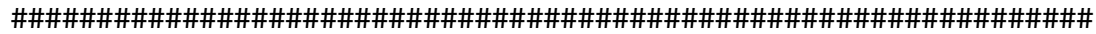

\begin{tabular}{|c|c|c|c|c|}
\hline & Estimate & Std. Error & t value & $\operatorname{Pr}(>|\mathrm{t}|)$ \\
\hline (Intercept) & -4.73187 & 0.26209 & -18.05 & $<2 \mathrm{e}-16^{* * *}$ \\
\hline demografia.d2 & 0.17221 & 0.01132 & 15.22 & $<2 \mathrm{e}-16^{* * *}$ \\
\hline
\end{tabular}

Signif. codes: $0^{(* * *)} 0.001^{(* * \prime} 0.01^{\prime * \prime} 0.05^{\prime \prime}, 0.1^{\prime \prime} 1$

Residual standard error: 1.047 on 313 degrees of freedom

Multiple R-squared: 0.4252, Adjusted R-squared: 0.4234

F-statistic: 231.6 on 1 and 313 DF, p-value: $<2.2 \mathrm{e}-16$ 
In adition, combining $\mathrm{d} 2$ and EMIG $_{50-91}$ does not add much -regressors are correlated:

\begin{tabular}{|c|c|c|c|c|}
\hline & Estimate & Std. Error & t value & $\operatorname{Pr}(>|\mathrm{t}|)$ \\
\hline (Intercept) & -2.67832 & 0.56572 & -4.734 & $3.34 \mathrm{e}-06^{* * *}$ \\
\hline EMIG.50-91 & 0.42726 & 0.10498 & 4.070 & $5.97 \mathrm{e}-05^{* * *}$ \\
\hline demografia.d2 & 0.09714 & 0.02150 & 4.518 & $8.85 \mathrm{e}-06^{* * *}$ \\
\hline
\end{tabular}

$--$

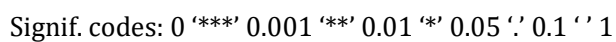

Residual standard error: 1.022 on 312 degrees of freedom

Multiple R-squared: 0.4542, Adjusted R-squared: 0.4507

F-statistic: 129.8 on 2 and 312 DF, p-value: $<2.2 \mathrm{e}-16$

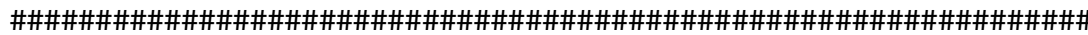

It would make sense to combine EMIG50-91 and d5, since the latter -the 85+ over 65+ ratio- is the only demographic indicator that is not correlated to EMIG50-91 (hence, this does not work as a good proxy of it). However, the regression does not add much, $\mathrm{d} 5$ results not significant, and adj- $\mathrm{R}^{2}$ values worsen.

\begin{tabular}{|c|c|c|c|c|}
\hline & Estimate & Std. Error & $t$ value & $\operatorname{Pr}(>|t|)$ \\
\hline (Intercept) & 0.11513 & 0.32763 & 0.351 & 0.726 \\
\hline EMIG.50-91 & 0.82711 & 0.05630 & 14.691 & $<2 \mathrm{e}-16^{* * *}$ \\
\hline demografia.d5 & -0.02769 & 0.03410 & -0.812 & 0.417. \\
\hline
\end{tabular}

$---$

Signif. codes: $0^{(* * *)} 0.001^{\prime * * \prime} 0.01^{\prime * \prime} 0.05$ '? $0.1^{\prime \prime \prime} 1$

Residual standard error: 1.054 on 312 degrees of freedom

Multiple R-squared: 0.4197, Adjusted R-squared: 0.416

F-statistic: 112.8 on 2 and 312 DF, p-value: $<2.2 \mathrm{e}-16$

Table A3. Variables used in the analysis

\begin{tabular}{|c|c|c|c|c|}
\hline Type & Name & Indicator & Description - estimation & Source \\
\hline \multirow{3}{*}{$\begin{array}{l}\text { Population } \\
\text { growth }\end{array}$} & EMIG.50-91 & $\begin{array}{l}\text { Emigration in years } \\
1950 \text { to } 1991\end{array}$ & $\begin{array}{l}\text { Annualized percentage of population growth rate } \\
\text { (population } 1991 \text { / population 1950) }\end{array}$ & INE (census) \\
\hline & DEPOP.91-11 & $\begin{array}{l}\text { Change in population, } \\
1991 \text { to } 2011\end{array}$ & $\begin{array}{l}\text { Annualized percentage of population growth rate } \\
\text { (population } 2011 \text { / population 1991) }\end{array}$ & INE (census) \\
\hline & RESID.91-11 & $\begin{array}{l}\text { Residuals of the } \\
\text { demographic drag, } \\
\text { 1991-2011 }\end{array}$ & $\begin{array}{l}\text { Annualized percentage of population growth rate } \\
\text { above (below) regression estimates }\end{array}$ & Own / INE \\
\hline \multirow{8}{*}{$\begin{array}{l}\text { Demographic } \\
\text { structure }\end{array}$} & d1 & Mean age & $\begin{array}{l}\text { Arithmetic average of all the inhabitants' age by } \\
\text { January } 1^{\text {st }}, 1991\end{array}$ & IGE \\
\hline & $\mathrm{d} 2$ & $\begin{array}{l}\% \text { population under } \\
20\end{array}$ & $\begin{array}{l}\text { Population under } 20 \text { years old over total } \\
\text { population, year } 1991\end{array}$ & IGE \\
\hline & d3 & $\begin{array}{l}\% \text { population aged } 65 \\
\text { and more }\end{array}$ & $\begin{array}{l}\text { Population aged } 65 \text { and more over total } \\
\text { population, year } 1991\end{array}$ & IGE \\
\hline & $\mathrm{d} 4$ & $\begin{array}{l}\text { Elderly dependency } \\
\text { ratio }\end{array}$ & $\begin{array}{l}\text { Population aged } 65 \text { and more / population under } \\
20 \text {, year } 1991\end{array}$ & IGE \\
\hline & d5 & $85+$ over $65+$ & $\begin{array}{l}\text { Population aged } 85+\text { / population aged } 65+\text {, year } \\
1991\end{array}$ & IGE \\
\hline & d6 & $\begin{array}{l}\text { Age-dependency } \\
\text { ratio }\end{array}$ & $\begin{array}{l}\text { Dependent population (under 15; } 65 \text { and more) / } \\
\text { population 15-64, year } 1991\end{array}$ & IGE \\
\hline & d7 & $\begin{array}{l}\text { Labour force } \\
\text { structure }\end{array}$ & $\begin{array}{l}\text { Population } 40-64 \text { years old / population } \\
15-39 \text { years old, year } 1991\end{array}$ & IGE \\
\hline & d8 & $\begin{array}{l}\text { Labour force } \\
\text { replacement }\end{array}$ & $\begin{array}{l}\text { Population } 60-64 \text { years old / population } \\
15-19 \text { years old, year } 1991\end{array}$ & IGE \\
\hline
\end{tabular}


Table A3 (continuation). Variables used in the analysis

\begin{tabular}{|c|c|c|c|c|}
\hline Type & Name & Indicator & Description - estimation & Source \\
\hline \multirow{7}{*}{$\begin{array}{l}\text { Geographic } \\
\text { variables }\end{array}$} & $\mathrm{x} 0$ & $\begin{array}{l}\text { Population of the county } \\
\text { capital }\end{array}$ & $\begin{array}{l}\text { Number of inhabitants of the municipality } \\
\text { capital of county }\end{array}$ & IGE \\
\hline & $\mathrm{x} 2$ & $\begin{array}{l}\text { Distance to the county } \\
\text { capital }\end{array}$ & Distance to the county capital $(\mathrm{km})$ & Googlemaps \\
\hline & $\mathrm{x} 2 \mathrm{~b}$ & & Ibidem, in minutes driving by road & \\
\hline & $\mathrm{x} 3$ & Distance to the closest city & $\begin{array}{l}\text { Distance to the closest city }(+50.000 \\
\text { inhababitants) in km }\end{array}$ & Googlemaps \\
\hline & $\mathrm{x} 3 \mathrm{~b}$ & & Ibidem, in minutes driving by road & \\
\hline & $\mathrm{x} 4$ & $\begin{array}{l}\text { Distance county capital - } \\
\text { Eixo Atlántico }\end{array}$ & $\begin{array}{l}\text { Distance in kilometers to the Eixo Atlántico } \\
\text { (proxy: closest airport) }\end{array}$ & Googlemaps \\
\hline & $\mathrm{x} 4 \mathrm{~b}$ & & Ibidem, in minutes driving by road & \\
\hline \multirow{5}{*}{ Population } & dens91 & Population density in 1991 & Total population in the 1991 census / km2 & INE, IGE \\
\hline & forei & Resident foreign people (\%) & $\begin{array}{l}\text { Percentage of foreign residents to total } \\
\text { population, year } 1991\end{array}$ & INE (census) \\
\hline & born & $\begin{array}{l}\text { Born in the municipality } \\
(\%)\end{array}$ & $\begin{array}{l}\text { Percentage of residents that were born in } \\
\text { the municipality to total population, year } \\
1991\end{array}$ & INE (census) \\
\hline & abroad & Born outside Galicia (\%) & $\begin{array}{l}\text { Percentage of residents that were born } \\
\text { outside Galicia to total population, year } \\
1991\end{array}$ & INE (census) \\
\hline & men & Percentage of men & $\begin{array}{l}\text { Percentage of men to total population, year } \\
1991\end{array}$ & INE (census) \\
\hline \multirow{3}{*}{ Education } & educ1 & $\begin{array}{l}\text { Illiterate population \& no } \\
\text { formal degree }(\%)\end{array}$ & $\begin{array}{l}\text { Illiterate people and literate without formal } \\
\text { education degree to total population, year } \\
1991\end{array}$ & INE (census) \\
\hline & educ2 & $\begin{array}{l}\text { Population with secondary } \\
\text { education }(\%)\end{array}$ & $\begin{array}{l}\text { Number of residents with a secondary } \\
\text { education degree to total population, year } \\
1991\end{array}$ & INE (census) \\
\hline & educ3 & $\begin{array}{l}\text { Population with tertiary } \\
\text { level education (\%) }\end{array}$ & $\begin{array}{l}\text { Number of residents with a university } \\
\text { degree to total population, year } 1991\end{array}$ & INE (census) \\
\hline \multirow{3}{*}{$\begin{array}{l}\text { Labour } \\
\text { market }\end{array}$} & activ & Activity rate & $\begin{array}{l}\text { Percentage of active resident population to } \\
\text { total population aged } 16 \text { or older, year } 1991\end{array}$ & INE, IGE \\
\hline & emplo & Employment rate & $\begin{array}{l}\text { Percentage of occupied residents to total } \\
\text { population aged } 16 \text { or older, year } 1991\end{array}$ & INE, IGE \\
\hline & unemp & Unemployment rate & $\begin{array}{l}\text { Percentage of unemployed residents to } \\
\text { total population aged } 16 \text { or older, year } 1991\end{array}$ & INE, IGE \\
\hline \multirow{6}{*}{ Quality of life } & income96 & $\begin{array}{l}\text { Disposable income per } \\
\text { capita }\end{array}$ & $\begin{array}{l}\text { Average disposable income per number of } \\
\text { residents in the municipality, year } 1996\end{array}$ & IGE \\
\hline & income 09 & $\begin{array}{l}\text { Disposable income per } \\
\text { capita }\end{array}$ & $\begin{array}{l}\text { Average disposable income per number of } \\
\text { residents in the municipality, year } 2009\end{array}$ & IGE \\
\hline & ISDN & Access to ISDN services & $\begin{array}{l}\text { Percentage of residents with access to } \\
\text { Integrated Services Digital Network, year } \\
2011\end{array}$ & $\begin{array}{l}\text { Mo Hacienda, } \\
\text { IGE }\end{array}$ \\
\hline & social & $\begin{array}{l}\text { Places in social services / } \\
1,000 \text { inhabs }\end{array}$ & $\begin{array}{l}\text { Number of places in social services centers } \\
\text { (elder people, disabilities, minors, family, } \\
\text { immigrants and community services) per } \\
1,000 \text { residents, year } 2011\end{array}$ & $\begin{array}{l}\text { C.Traballo, } \\
\text { IGE }\end{array}$ \\
\hline & tour & $\begin{array}{l}\text { Beds in hotels and campings } \\
\text { to population }\end{array}$ & $\begin{array}{l}\text { Number of beds in hotels, rural houses and } \\
\text { campsites, pero 1,000 residents, year } 2011\end{array}$ & C.Cultura, IGE \\
\hline & work & $\begin{array}{l}\text { work accidents / 1,000 } \\
\text { inhabs }\end{array}$ & $\begin{array}{l}\text { Number of work accidents with registered } \\
\text { leave, per } 1,000 \text { residents, year } 2001\end{array}$ & $\begin{array}{l}\text { C.Traballo, } \\
\text { IGE }\end{array}$ \\
\hline
\end{tabular}


Table A3 (continuation). Variables used in the analysis

\begin{tabular}{|c|c|c|c|c|}
\hline Type & Name & Indicator & Description - estimation & Source \\
\hline \multirow{5}{*}{$\begin{array}{l}\text { Employment } \\
\text { structure }\end{array}$} & emp1 & Employees in farming (\%) & $\begin{array}{l}\text { Residents employed in the farming sector to total } \\
\text { number of employed residents, year } 1991\end{array}$ & IGE \\
\hline & emp2 & Employees in fishing (\%) & $\begin{array}{l}\text { Residents employed in the fishing sector to total } \\
\text { number of employed residents, year } 1991\end{array}$ & IGE \\
\hline & emp3 & Employees in industry (\%) & $\begin{array}{l}\text { Residents employed in the industrial sector to } \\
\text { total number of employed residents, year } 1991\end{array}$ & IGE \\
\hline & emp4 & Employees in construction (\%) & $\begin{array}{l}\text { Residents employed in the construction sector to } \\
\text { total number of employed residents, year } 1991\end{array}$ & IGE \\
\hline & emp5 & Employees in services (\%) & $\begin{array}{l}\text { Residents employed in the services sector to } \\
\text { total number of employd residents, year } 1991\end{array}$ & IGE \\
\hline \multirow{6}{*}{$\begin{array}{l}\text { Business } \\
\text { Financial } \\
\text { results }\end{array}$} & b1r & $\begin{array}{l}\text { Total sales revenues to } \\
\text { population }\end{array}$ & $\begin{array}{l}\text { Sum of firms' sales revenues average 2001-2010, } \\
\text { divided by municipality's population in year } \\
2011\end{array}$ & SABI \\
\hline & $\mathrm{b} 2 \mathrm{r}$ & Total assets to population & $\begin{array}{l}\text { Sum of firms' total assets average } 2001-2010 \text {, } \\
\text { divided by municipality's population in year } \\
2011\end{array}$ & SABI \\
\hline & b3r & Total equity to population & $\begin{array}{l}\text { Sum of firms' equity average } 2001-2010 \text {, divided } \\
\text { by municipality's population in year } 2011\end{array}$ & SABI \\
\hline & $\mathrm{b} 4 \mathrm{r}$ & $\begin{array}{l}\text { Sum of earnings before taxes } \\
\text { to population }\end{array}$ & $\begin{array}{l}\text { Sum of firms' EBT average 2001-2010, divided } \\
\text { by municipality's population in year } 2011\end{array}$ & SABI \\
\hline & b5 & Average ROA & $\begin{array}{l}\text { Firms' average return on assets over years } \\
2001-2010\end{array}$ & SABI \\
\hline & b6r & Total employees to population & $\begin{array}{l}\text { Total number of employees, average } 2001-2010 \text {, } \\
\text { divided by municipality's population in year } \\
2011\end{array}$ & SABI \\
\hline \multirow{4}{*}{$\begin{array}{l}\text { Business } \\
\text { density }\end{array}$} & $\mathrm{b} 7 \mathrm{r}$ & $\begin{array}{l}\text { Number of firms / 1,000 } \\
\text { inhabs }\end{array}$ & $\begin{array}{l}\text { Ratio total number of firms in the council (year } \\
2010 \text { ) per } 1,000 \text { inhabitants (census year 2011) }\end{array}$ & IGE \\
\hline & b7ir & $\begin{array}{l}\text { Firms in industrial sectors / } \\
1,000 \text { inhabs }\end{array}$ & $\begin{array}{l}\text { Ratio number of firms in industrial sectors (year } \\
\text { 2010) per 1,000 inhabs. (census year 2011) }\end{array}$ & IGE \\
\hline & $\mathrm{b} 7 \mathrm{cr}$ & $\begin{array}{l}\text { Firms in construction sector / } \\
1,000 \text { inhabs }\end{array}$ & $\begin{array}{l}\text { Ratio number of firms in construction sector } \\
\text { (year 2010) per 1,000 inhabs. (census year } \\
\text { 2011) }\end{array}$ & IGE \\
\hline & b7sr & $\begin{array}{l}\text { Firms in services sector / } \\
1,000 \text { inhabs }\end{array}$ & $\begin{array}{l}\text { Ratio number of firms in services sector (year } \\
2010 \text { ) per } 1,000 \text { inhabitants (census year } 2011 \text { ) }\end{array}$ & IGE \\
\hline
\end{tabular}

Mo Hacienda stands for Spanish Treasury, C.Traballo and C.Cultura stand for Galician Ministry of Work and of Culture, respectively. INE is the Spanish Statistics Institute, IGE the Galician Statistics Institute, and SABI stands for SABI - Bureau van Dijk database.

Data treatment: For population growth, we use population data from the INE censuses of 1950,1991 e 2011. We take into account all changes in the municipality map since 1950 following Míguez (2013). For the 1950 census we consider de jure population, and we sum the population in 1950 of councils when these merged afterwards. These include Buxán added to Val do Dubra, A Enfesta to Santiago de Compostela, Neira de Jusá to Baralla; Riobarba to 0 Vicedo; Vilaodrid to A Pontenova. Acebedo del Río to Celanova, Rio to San Xoan de Rio, and Pontesampaio to Pontevedra. In addition, we allot population between councils, according to their population in the 1991 census, when these split. This includes Cariño from Ortigueira in 1988. Finally, a typo in Narón data was amended: according to de jure population, its inhabitants in year 1950 were 14,895. For the 1950 and 1991 census we allot population between councils that split after 1991 according to their population in the 2001 census. These include the split of Burela from Cervo in 1994, and A Illa de Arousa from Vilanova de Arousa in 1996. For data on demographic structure, population and labour market, which refer to year 1991, for those two new-born councils in 1994 and 1996 we took the same data of the councils from which they split.

In regards to distances by road from county capitals to county capitals, Galician cities and the Eixo Atlántico -using the closest of the three Galician airports as a proxy-we selected the quickest route according to googlemaps, as it takes the quality of the roads into account, and measured the distance in kilometers and driving time in minutes for that route. INE statistics about education level (from which we estimated indicators e1, e2 and e3) omit some data for 23 councils when "only a few sample observations were available". In such case we allot any missing population among the education levels with no data using Galician averages. This basically afected solely our estimations of indicator e3 for 22 of those 23 councils. Finally, data on GVA as a percentage of county's GDP, uses data available at the county level and assumes the same structure for its municipalities.

Source: Own elaboration. 
Table A4. Robustness of the PCA rotation methods

\begin{tabular}{|c|c|c|c|c|c|c|c|c|c|c|}
\hline \multicolumn{11}{|c|}{ Varimax Rotation - 10 components } \\
\hline \#\# & $\mathrm{RC} 1$ & RC2 & RC5 & RC4 & RC3 & RC6 & RC7 & RC8 & $\mathrm{RC} 10$ & RC9 \\
\hline \#\# DEPOP.9111 & -0.461 & 0.164 & -0.384 & 0.351 & 0.138 & & & 0.152 & 0.507 & -0.153 \\
\hline \#\# RESID.9111 & & & -0.393 & 0.298 & 0.167 & & 0.105 & 0.111 & 0.578 & -0.232 \\
\hline \#\# d1 & 0.963 & -0.121 & 0.101 & -0.112 & & & & & & \\
\hline \#\# d2 & -0.929 & 0.105 & -0.118 & & & & & 0.106 & & \\
\hline \#\# d3 & 0.956 & -0.116 & 0.131 & & & & & & & \\
\hline \#\# d4 & 0.938 & & 0.141 & & & & & & & \\
\hline \#\# d5 & & -0.116 & & & & & & -0.165 & 0.113 & 0.647 \\
\hline \#\# d6 & 0.819 & & 0.136 & & 0.148 & & & & 0.173 & \\
\hline \#\# d7 & 0.856 & & & -0.244 & & & & & 0.116 & \\
\hline \#\# d8 & 0.902 & & 0.108 & & & & & -0.118 & & \\
\hline \#\# x0 & -0.136 & 0.239 & -0.435 & 0.116 & & 0.573 & & & 0.130 & -0.184 \\
\hline \#\# log_x0 & -0.256 & 0.172 & -0.455 & & & 0.609 & & & 0.180 & -0.152 \\
\hline \#\# x2 & & & 0.111 & -0.137 & & 0.887 & & & -0.139 & 0.126 \\
\hline$\# \# x 2 b$ & & & 0.102 & -0.175 & & 0.885 & & & & 0.140 \\
\hline \#\# x3 & & & 0.901 & & 0.133 & & -0.128 & & & \\
\hline \#\# x3b & & & 0.909 & & & & & & & \\
\hline \#\# x4 & 0.523 & & 0.712 & 0.127 & & & -0.123 & & & \\
\hline \#\# x4b & 0.490 & & 0.771 & & & & -0.121 & & & \\
\hline \#\# dens91 & -0.537 & & -0.180 & 0.230 & 0.203 & & & & & 0.270 \\
\hline \#\# forei & & 0.111 & 0.252 & & & & -0.719 & & & \\
\hline \#\# born & 0.148 & -0.251 & 0.145 & -0.667 & & & 0.299 & & -0.261 & 0.130 \\
\hline \#\# abroad & & & 0.301 & 0.286 & & & -0.767 & & 0.137 & -0.152 \\
\hline \#\# men & & & 0.469 & & -0.215 & & 0.449 & -0.125 & -0.220 & -0.320 \\
\hline \#\# educ1 & 0.359 & -0.114 & 0.207 & -0.428 & -0.156 & & 0.116 & 0.137 & 0.101 & -0.411 \\
\hline \#\# educ2 & -0.437 & 0.118 & -0.122 & 0.669 & & & & & & 0.164 \\
\hline \#\# educ3 & & & & 0.840 & & -0.133 & & & & \\
\hline \#\# activ & -0.213 & & & & -0.864 & & & & & \\
\hline \#\# emplo & & & & & -0.943 & & & & & \\
\hline \#\# unemp & -0.209 & & & & 0.786 & & -0.130 & -0.197 & -0.160 & \\
\hline \#\# income96 & & 0.234 & 0.141 & 0.472 & & & & 0.192 & 0.477 & \\
\hline \#\# income09 & -0.208 & & 0.105 & 0.566 & -0.157 & & 0.502 & 0.223 & 0.200 & \\
\hline \#\# ISDN & -0.445 & & & 0.132 & & & 0.447 & & 0.266 & \\
\hline \#\# social & 0.151 & & & 0.154 & & & -0.296 & & 0.474 & \\
\hline \#\# tour & & & 0.194 & 0.238 & & 0.113 & & & & 0.550 \\
\hline \#\# work & -0.152 & 0.741 & 0.138 & & & & -0.119 & 0.226 & 0.134 & \\
\hline \#\# emp1 & 0.630 & -0.189 & & -0.243 & -0.577 & & & -0.129 & -0.181 & -0.152 \\
\hline \#\# emp2 & -0.477 & & 0.344 & -0.142 & 0.120 & & 0.232 & & 0.234 & 0.293 \\
\hline \#\# emp3 & -0.368 & 0.455 & & 0.170 & 0.332 & & & & 0.264 & \\
\hline \#\# emp4 & -0.398 & & -0.209 & -0.213 & 0.491 & & -0.207 & 0.363 & & \\
\hline \#\# emp5 & -0.439 & & -0.124 & 0.560 & 0.486 & & -0.107 & & & 0.129 \\
\hline \#\# b1r & & 0.956 & & & & & & & & \\
\hline \#\# b2r & -0.117 & 0.931 & & & & & & & & \\
\hline \#\# b3r & & 0.979 & & & & & & & & \\
\hline \#\# b4r & & 0.873 & & & & & & & & \\
\hline \#\# b5 & -0.127 & & & 0.113 & & 0.129 & & & -0.441 & -0.214 \\
\hline \#\# b6r & -0.124 & 0.931 & & & & & & 0.166 & & \\
\hline \#\# b7r & -0.279 & 0.209 & & 0.510 & -0.101 & & 0.155 & 0.719 & & \\
\hline \#\# b7ir & & 0.400 & & & & & -0.173 & 0.615 & & -0.154 \\
\hline \#\# b7cr & -0.165 & & -0.139 & & & & & 0.800 & & \\
\hline \#\# b7sr & -0.327 & 0.139 & & 0.646 & -0.120 & & 0.224 & 0.473 & & \\
\hline \multicolumn{11}{|l|}{ \#\# } \\
\hline \#\# & $\mathrm{RC} 1$ & $\mathrm{RC} 2$ & RC5 & $\mathrm{RC} 4$ & $\mathrm{RC} 3$ & RC6 & $\mathrm{RC7}$ & RC8 & $\mathrm{RC} 10$ & RC9 \\
\hline \#\# ss loadings & 9.060 & 5.803 & 4.385 & 4.177 & 3.537 & 2.427 & 2.339 & 2.336 & 1.886 & 1.559 \\
\hline \#\# Proportion Var & 0.181 & 0.116 & 0.088 & 0.084 & 0.071 & 0.049 & 0.047 & 0.047 & 0.038 & 0.031 \\
\hline \#\# Cumulative Var & 0.181 & 0.297 & 0.385 & 0.469 & 0.539 & 0.588 & 0.635 & 0.681 & 0.719 & 0.750 \\
\hline
\end{tabular}


Table A4 (continuation). Robustness of the PCA rotation methods

\begin{tabular}{|c|c|c|c|c|c|c|c|c|c|}
\hline \multicolumn{10}{|c|}{ Varimax Rotation - 9 components } \\
\hline \#\# & $\mathrm{RC} 1$ & $\mathrm{RC} 2$ & RC4 & RC5 & RC3 & RC6 & $\mathrm{RC7}$ & RC8 & RC9 \\
\hline \#\# DEPOP.9111 & -0.409 & 0.162 & 0.477 & -0.479 & 0.169 & & & 0.249 & \\
\hline \#\# RESID.9111 & & & 0.447 & -0.507 & 0.203 & 0.136 & & 0.242 & \\
\hline \#\# d1 & 0.962 & -0.120 & -0.103 & & & & & & \\
\hline \#\# d2 & -0.920 & 0.106 & & -0.123 & 0.100 & & & 0.123 & \\
\hline \#\# d3 & 0.955 & -0.115 & & 0.126 & & & & & \\
\hline \#\# d4 & 0.935 & & & 0.140 & & & & & \\
\hline \#\# d5 & & -0.107 & & & & & -0.102 & -0.188 & 0.645 \\
\hline \#\# d6 & 0.829 & & & 0.117 & 0.156 & & & 0.101 & 0.161 \\
\hline \#\# d7 & 0.870 & & -0.209 & & & & & & \\
\hline \#\# d8 & 0.909 & & & & & & & & \\
\hline \#\# x0 & -0.121 & 0.234 & 0.132 & -0.486 & 0.103 & 0.562 & & & -0.139 \\
\hline \#\# log_x0 & -0.235 & 0.168 & 0.131 & -0.509 & & 0.605 & & & \\
\hline \#\# x2 & & & -0.149 & 0.120 & & 0.868 & & -0.101 & \\
\hline \#\# x2b & & & -0.177 & 0.102 & & 0.877 & & & \\
\hline \#\# x3 & & & & 0.891 & 0.146 & & 0.148 & & \\
\hline \#\# x3b & & & & 0.901 & & & 0.113 & & \\
\hline \#\# x4 & 0.530 & & 0.140 & 0.692 & & & 0.168 & & -0.103 \\
\hline \#\# x4b & 0.499 & & 0.104 & 0.754 & & & 0.161 & & \\
\hline \#\# dens91 & -0.553 & 0.100 & 0.240 & -0.170 & 0.204 & & & & 0.255 \\
\hline \#\# forei & & 0.113 & & 0.220 & & & 0.734 & & \\
\hline \#\# born & 0.148 & -0.244 & -0.660 & 0.209 & & & -0.400 & & \\
\hline \#\# abroad & & & 0.215 & 0.250 & 0.107 & & 0.824 & & \\
\hline \#\# men & & & 0.105 & 0.462 & -0.209 & 0.100 & -0.416 & -0.126 & -0.404 \\
\hline \#\# educ1 & 0.418 & -0.112 & -0.322 & 0.154 & -0.143 & 0.151 & & 0.303 & -0.301 \\
\hline \#\# educ2 & -0.472 & 0.111 & 0.611 & -0.112 & & -0.135 & & -0.218 & \\
\hline \#\# educ3 & & & 0.792 & & & -0.183 & 0.175 & -0.146 & \\
\hline \#\# activ & -0.220 & & & & -0.868 & & & & \\
\hline \#\# emplo & & & & & -0.944 & & & & \\
\hline \#\# unemp & -0.225 & & & & 0.778 & & 0.113 & -0.233 & -0.110 \\
\hline \#\# income96 & 0.122 & 0.233 & 0.616 & & & & & 0.237 & 0.163 \\
\hline \#\# income09 & -0.194 & & 0.692 & & -0.139 & & -0.407 & 0.178 & \\
\hline \#\# ISDN & -0.395 & & 0.269 & & & & -0.381 & 0.132 & \\
\hline \#\# social & 0.185 & & 0.245 & & & & 0.373 & 0.180 & 0.259 \\
\hline \#\# tour & & & 0.240 & 0.245 & & & & & 0.448 \\
\hline \#\# work & -0.139 & 0.743 & & 0.108 & & 0.104 & 0.147 & 0.247 & \\
\hline \#\# emp1 & 0.632 & -0.190 & -0.266 & & -0.585 & & -0.103 & -0.118 & -0.168 \\
\hline \#\# emp2 & -0.439 & & & 0.326 & 0.146 & 0.169 & -0.216 & & 0.353 \\
\hline \#\# emp3 & -0.341 & 0.455 & 0.231 & & 0.350 & & & 0.110 & \\
\hline \#\# emp4 & -0.420 & & -0.228 & -0.187 & 0.473 & & 0.154 & 0.347 & \\
\hline \#\# emp5 & -0.470 & & 0.505 & -0.127 & 0.485 & & 0.144 & -0.118 & \\
\hline \#\# b1r & -0.101 & 0.954 & & & & & & & \\
\hline \#\# b2r & -0.119 & 0.930 & 0.100 & & & & & & \\
\hline \#\# b3r & & 0.978 & & & & & & & \\
\hline \#\# b4r & & 0.871 & & & & & & & \\
\hline \#\# b5 & -0.169 & & & 0.124 & & & -0.127 & & -0.399 \\
\hline \#\# b6r & -0.130 & 0.931 & 0.101 & & & & & 0.135 & \\
\hline \#\# b7r & -0.315 & 0.205 & 0.579 & & -0.115 & -0.154 & -0.116 & 0.567 & \\
\hline \#\# b7ir & & 0.402 & & & & & 0.187 & 0.587 & -0.135 \\
\hline \#\# b7cr & -0.180 & & 0.122 & -0.137 & & -0.124 & & 0.758 & \\
\hline \#\# b7sr & -0.365 & 0.132 & 0.681 & & -0.131 & -0.133 & -0.176 & 0.300 & \\
\hline \multicolumn{10}{|l|}{ \#\# } \\
\hline \#\# & $\mathrm{RC} 1$ & $\mathrm{RC} 2$ & $\mathrm{RC} 4$ & RC5 & RC3 & RC6 & RC7 & RC8 & RC9 \\
\hline \#\# ss loadings & 9.198 & 5.776 & 4.630 & 4.501 & 3.567 & 2.471 & 2.427 & 2.188 & 1.542 \\
\hline \#\# Proportion Var & 0.184 & 0.116 & 0.093 & 0.090 & 0.071 & 0.049 & 0.049 & 0.044 & 0.031 \\
\hline \#\# Cumulative Var & 0.184 & 0.299 & 0.392 & 0.482 & 0.553 & 0.603 & 0.651 & 0.695 & 0.726 \\
\hline
\end{tabular}


Table A4 (continuation). Robustness of the PCA rotation methods

\begin{tabular}{|c|c|c|c|c|c|c|c|c|c|c|c|}
\hline \multicolumn{12}{|c|}{ Varimax Rotation - 8 components, complete results } \\
\hline \#\# & RC1 & $\mathrm{RC} 2$ & $\mathrm{RC} 4$ & RC5 & RC3 & RC6 & RC7 & RC8 & h2 & u2 & com \\
\hline \#\# DEPOP.9111 & -0.40 & 0.16 & 0.50 & -0.49 & 0.18 & 0.09 & 0.01 & 0.20 & 0.75 & 0.250 & 3.8 \\
\hline \#\# RESID.9111 & 0.08 & 0.08 & 0.46 & -0.51 & 0.19 & 0.14 & 0.01 & 0.20 & 0.58 & 0.416 & 2.9 \\
\hline \#\# d1 & 0.96 & -0.12 & -0.11 & 0.10 & -0.03 & -0.01 & 0.03 & -0.06 & 0.97 & 0.033 & 1.1 \\
\hline$\# \# \mathrm{~d} 2$ & -0.91 & 0.10 & 0.10 & -0.13 & 0.13 & 0.02 & -0.06 & 0.10 & 0.90 & 0.097 & 1.2 \\
\hline \#\# d3 & 0.96 & -0.11 & -0.07 & 0.13 & 0.03 & -0.01 & 0.03 & -0.04 & 0.96 & 0.045 & 1.1 \\
\hline$\# \# \mathrm{~d} 4$ & 0.94 & -0.09 & -0.07 & 0.14 & 0.02 & 0.00 & 0.01 & -0.10 & 0.92 & 0.078 & 1.1 \\
\hline \#\# d5 & 0.09 & -0.13 & 0.06 & 0.01 & 0.02 & 0.05 & -0.16 & -0.41 & 0.22 & 0.779 & 1.7 \\
\hline \#\# d6 & 0.84 & -0.09 & 0.00 & 0.12 & 0.17 & 0.02 & -0.03 & 0.03 & 0.76 & 0.243 & 1.2 \\
\hline \#\# d7 & 0.87 & -0.10 & -0.20 & -0.04 & 0.01 & -0.02 & -0.02 & -0.01 & 0.82 & 0.184 & 1.1 \\
\hline \#\# d8 & 0.91 & -0.08 & -0.06 & 0.10 & -0.08 & 0.00 & -0.02 & -0.10 & 0.86 & 0.141 & 1.1 \\
\hline \#\# x0 & -0.13 & 0.24 & 0.10 & -0.48 & 0.07 & 0.57 & 0.04 & 0.00 & 0.64 & 0.361 & 2.6 \\
\hline \#\# log_x0 & -0.24 & 0.17 & 0.12 & -0.50 & 0.03 & 0.61 & -0.02 & 0.07 & 0.73 & 0.271 & 2.6 \\
\hline \#\# x2 & 0.05 & -0.01 & -0.14 & 0.14 & -0.06 & 0.87 & -0.02 & -0.12 & 0.81 & 0.191 & 1.2 \\
\hline \#\# x2b & 0.05 & 0.06 & -0.16 & 0.12 & -0.03 & 0.88 & 0.03 & -0.12 & 0.83 & 0.169 & 1.2 \\
\hline \#\# x3 & 0.09 & 0.02 & -0.04 & 0.89 & 0.15 & 0.01 & 0.17 & 0.01 & 0.85 & 0.150 & 1.2 \\
\hline \#\# x3b & 0.07 & 0.04 & -0.03 & 0.90 & 0.10 & 0.07 & 0.13 & -0.02 & 0.85 & 0.154 & 1.1 \\
\hline \#\# x4 & 0.52 & 0.03 & 0.12 & 0.69 & 0.03 & -0.03 & 0.21 & 0.01 & 0.81 & 0.191 & 2.2 \\
\hline$\# \#$ x4b & 0.49 & 0.03 & 0.10 & 0.75 & 0.01 & 0.01 & 0.20 & -0.04 & 0.86 & 0.142 & 2.0 \\
\hline \#\# dens91 & -0.54 & 0.09 & 0.29 & -0.18 & 0.24 & -0.01 & -0.07 & -0.09 & 0.48 & 0.518 & 2.5 \\
\hline \#\# forei & -0.03 & 0.10 & -0.09 & 0.19 & 0.11 & 0.06 & 0.72 & 0.07 & 0.60 & 0.396 & 1.3 \\
\hline \#\# born & 0.15 & -0.25 & -0.61 & 0.23 & -0.06 & 0.00 & -0.45 & -0.01 & 0.72 & 0.284 & 2.7 \\
\hline \#\# abroad & 0.01 & 0.07 & 0.15 & 0.22 & 0.10 & -0.02 & 0.85 & 0.02 & 0.82 & 0.184 & 1.2 \\
\hline \#\# men & 0.04 & 0.07 & 0.05 & 0.49 & -0.29 & 0.08 & -0.32 & -0.01 & 0.44 & 0.561 & 2.6 \\
\hline \#\# educ1 & 0.40 & -0.11 & -0.32 & 0.18 & -0.16 & 0.16 & -0.11 & 0.40 & 0.53 & 0.469 & 4.3 \\
\hline \#\# educ2 & -0.47 & 0.12 & 0.58 & -0.13 & -0.01 & -0.15 & 0.10 & -0.26 & 0.69 & 0.308 & 2.8 \\
\hline \#\# educ3 & -0.09 & -0.03 & 0.74 & 0.00 & 0.00 & -0.20 & 0.26 & -0.17 & 0.69 & 0.309 & 1.6 \\
\hline \#\# activ & -0.23 & 0.05 & 0.00 & -0.06 & -0.86 & -0.01 & -0.03 & -0.05 & 0.80 & 0.199 & 1.2 \\
\hline \#\# emplo & -0.10 & 0.05 & 0.02 & -0.07 & -0.93 & 0.00 & -0.07 & 0.03 & 0.88 & 0.119 & 1.1 \\
\hline \#\# unemp & -0.22 & -0.04 & -0.10 & 0.09 & 0.75 & -0.04 & 0.15 & -0.19 & 0.69 & 0.315 & 1,5 \\
\hline \#\# income96 & 0.13 & 0.22 & 0.66 & 0.05 & -0.02 & 0.00 & 0.06 & 0.14 & 0.52 & 0.476 & 1.4 \\
\hline \#\# income09 & -0.20 & 0.03 & 0.72 & 0.07 & -0.15 & 0.06 & -0.36 & 0.09 & 0.74 & 0.262 & 1.8 \\
\hline \#\# ISDN & -0.40 & 0.04 & 0.31 & 0.06 & -0.06 & 0.01 & -0.37 & 0.06 & 0.40 & 0.598 & 3.1 \\
\hline \#\# social & 0.20 & 0.04 & 0.29 & -0.03 & 0.12 & 0.01 & 0.33 & 0.09 & 0.26 & 0.739 & 3.2 \\
\hline \#\# tour & -0.07 & -0.05 & 0.32 & 0.23 & 0.06 & 0.08 & -0.11 & -0.21 & 0.23 & 0.769 & 3.5 \\
\hline \#\# work & -0.14 & 0.73 & 0.13 & 0.11 & -0.03 & 0.11 & 0.13 & 0.25 & 0.67 & 0.327 & 1.6 \\
\hline \#\# emp1 & 0.61 & -0.18 & -0.31 & 0.09 & -0.62 & -0.01 & -0.09 & -0.03 & 0.90 & 0.104 & 2.7 \\
\hline \#\# emp2 & -0.42 & -0.06 & 0.06 & 0.33 & 0.20 & 0.17 & -0.25 & -0.09 & 0.43 & 0.567 & 3.8 \\
\hline \#\# emp3 & -0.33 & 0.45 & 0.25 & -0.08 & 0.36 & 0.06 & 0.08 & 0.08 & 0.53 & 0.471 & 3.8 \\
\hline \#\# emp4 & -0.40 & -0.05 & -0.18 & -0.20 & 0.52 & -0.04 & 0.08 & 0.32 & 0.62 & 0.385 & 3.4 \\
\hline \#\# emp5 & -0.46 & 0.05 & 0.49 & -0.15 & 0.48 & -0.09 & 0.18 & -0.17 & 0.77 & 0.234 & 3.8 \\
\hline \#\# b1r & -0.11 & 0.96 & 0.07 & -0.06 & -0.04 & 0.02 & -0.01 & 0.05 & 0.94 & 0.063 & 1.1 \\
\hline \#\# b2r & -0.12 & 0.93 & 0.10 & 0.06 & -0.03 & 0.05 & 0.07 & 0.05 & 0.90 & 0.100 & 1.1 \\
\hline \#\# b3r & -0.10 & 0.98 & 0.06 & 0.02 & -0.02 & 0.05 & 0.03 & 0.03 & 0.97 & 0.028 & 1.0 \\
\hline \#\# b4r & -0.06 & 0.88 & 0.02 & -0.05 & 0.02 & 0.02 & -0.03 & -0.04 & 0.78 & 0.224 & 1.0 \\
\hline \#\# b5 & -0.19 & 0.10 & -0.05 & 0.14 & -0.01 & 0.06 & -0.06 & 0.07 & 0.08 & 0.920 & 3.5 \\
\hline \#\# b6r & -0.13 & 0.93 & 0.11 & -0.04 & -0.03 & 0.03 & 0.04 & 0.16 & 0.92 & 0.083 & 1.1 \\
\hline \#\# b7r & -0.31 & 0.19 & 0.63 & -0.04 & -0.10 & -0.15 & -0.12 & 0.53 & 0.86 & 0.144 & 3.0 \\
\hline \#\# b7ir & 0.06 & 0.38 & 0.14 & -0.02 & -0.06 & -0.07 & 0.14 & 0.61 & 0.57 & 0.425 & 2.0 \\
\hline \#\# b7cr & -0.17 & 0.01 & 0.21 & -0.14 & 0.07 & -0.11 & -0.16 & 0.71 & 0.64 & 0.364 & 1.6 \\
\hline \#\# b7sr & -0.37 & 0.13 & 0.70 & 0.01 & -0.14 & -0.14 & -0.14 & 0.26 & 0.77 & 0.231 & 2.2 \\
\hline \multicolumn{12}{|l|}{ \#\# } \\
\hline \#\# & RC1 & $\mathrm{RC} 2$ & RC4 & RC5 & RC3 & RC6 & RC7 & RC8 & & & \\
\hline \#\# ss loadings & 9.12 & 5.73 & 4.79 & 4.52 & 3.65 & 2.48 & 2.48 & 2.17 & & & \\
\hline \#\# Proportion Var & 0.18 & 0.11 & 0.10 & 0.09 & 0.07 & 0.05 & 0.05 & 0.04 & & & \\
\hline \#\# Cumulative Var & 0.18 & 0.30 & 0.39 & 0.48 & 0.56 & 0.61 & 0.66 & 0.70 & & & \\
\hline \multirow{2}{*}{\multicolumn{12}{|c|}{$\begin{array}{l}\# \# \\
\# \# \text { Mean item complexity }=2.1\end{array}$}} \\
\hline & & & & & & & & & & & \\
\hline \#\# Test of the hypot & esis that & & & -1 & & & & & & & \\
\hline \#\# The root mean & & & & & & & & & & & \\
\hline (1) & & & & & & & & & & & \\
\hline
\end{tabular}


Table A4 (continuation). Robustness of the PCA rotation methods

\begin{tabular}{|c|c|c|c|c|c|c|c|}
\hline \multicolumn{8}{|c|}{ Varimax Rotation - 7 components } \\
\hline \#\# & RC1 & $\mathrm{RC} 2$ & RC4 & RC5 & RC3 & RC6 & RC7 \\
\hline \#\# DEPOP.9111 & -0.394 & 0.209 & 0.482 & -0.489 & 0.191 & & 0.185 \\
\hline \#\# RESID.9111 & & 0.140 & 0.450 & -0.515 & 0.214 & & 0.183 \\
\hline \#\# d1 & 0.958 & -0.137 & & 0.108 & & & \\
\hline \#\# d2 & -0.909 & 0.126 & & -0.135 & 0.135 & & 0.113 \\
\hline \#\# d3 & 0.954 & -0.127 & & 0.133 & & & \\
\hline \#\# d4 & 0.928 & -0.120 & & 0.152 & & & \\
\hline \#\# d5 & & -0.253 & & & & 0.222 & \\
\hline \#\# d6 & 0.837 & & & 0.120 & 0.169 & & \\
\hline \#\# d7 & 0.873 & -0.111 & -0.179 & & & & \\
\hline \#\# d8 & 0.897 & -0.117 & & 0.112 & & & \\
\hline \#\# x0 & -0.121 & 0.267 & 0.110 & -0.505 & & 0.510 & \\
\hline \#\# log_x0 & -0.226 & 0.220 & 0.109 & -0.536 & & 0.519 & 0.117 \\
\hline \#\# x2 & & & -0.154 & & & 0.835 & \\
\hline$\# \# \mathrm{x} 2 \mathrm{~b}$ & & & -0.163 & & & 0.847 & \\
\hline \#\# x3 & & & & 0.882 & 0.167 & & -0.133 \\
\hline \#\# x3b & & & & 0.891 & 0.110 & & -0.103 \\
\hline \#\# x4 & 0.528 & & 0.144 & 0.692 & & & -0.136 \\
\hline \#\# x4b & 0.497 & & 0.120 & 0.753 & & & -0.146 \\
\hline \#\# dens91 & -0.555 & & 0.276 & -0.166 & 0.208 & & \\
\hline \#\# forei & & 0.186 & & 0.183 & 0.166 & & -0.598 \\
\hline \#\# born & 0.142 & -0.277 & -0.701 & 0.214 & & & 0.248 \\
\hline \#\# abroad & & 0.142 & 0.332 & 0.220 & 0.153 & & -0.675 \\
\hline \#\# men & & & & 0.481 & -0.300 & 0.124 & 0.300 \\
\hline \#\# educ1 & 0.444 & & -0.384 & 0.129 & & & 0.229 \\
\hline \#\# educ2 & -0.500 & & 0.614 & & & & \\
\hline \#\# educ3 & -0.112 & & 0.794 & & & -0.139 & -0.130 \\
\hline \#\# activ & -0.227 & & & & -0.855 & & \\
\hline \#\# emplo & & & & & -0.913 & & \\
\hline \#\# unemp & -0.238 & & & 0.109 & 0.717 & & -0.251 \\
\hline \#\# income96 & 0.131 & 0.258 & 0.639 & & & & 0.156 \\
\hline \#\# income09 & -0.211 & & 0.601 & & -0.175 & & 0.536 \\
\hline \#\# ISDN & -0.406 & & 0.203 & & & & 0.421 \\
\hline \#\# social & 0.217 & & 0.353 & & 0.139 & & -0.178 \\
\hline \#\# tour & & -0.106 & 0.291 & 0.252 & & 0.177 & \\
\hline \#\# work & -0.125 & 0.791 & 0.127 & & & & \\
\hline \#\# emp1 & 0.619 & -0.181 & -0.326 & & -0.604 & & \\
\hline \#\# emp2 & -0.436 & & & 0.321 & 0.183 & 0.217 & 0.215 \\
\hline \#\# emp3 & -0.337 & 0.455 & 0.265 & & 0.356 & & \\
\hline \#\# emp4 & -0.376 & & -0.165 & -0.215 & 0.571 & -0.186 & \\
\hline \#\# emp5 & -0.480 & & 0.542 & -0.114 & 0.435 & & -0.137 \\
\hline \#\# b1r & -0.121 & 0.921 & & & & & \\
\hline \#\# b2r & -0.133 & 0.908 & 0.108 & & & & \\
\hline \#\# b3r & -0.112 & 0.944 & & & & & \\
\hline \#\# b4r & & 0.816 & & & & & \\
\hline \#\# b5 & -0.185 & 0.117 & & 0.127 & & & \\
\hline \#\# b6r & -0.135 & 0.932 & 0.109 & & & & \\
\hline \#\# b7r & -0.288 & 0.324 & 0.532 & & & -0.332 & 0.466 \\
\hline \#\# b7ir & 0.109 & 0.554 & 0.110 & & & -0.297 & 0.157 \\
\hline \#\# b7cr & -0.123 & 0.198 & 0.112 & -0.170 & 0.161 & -0.371 & 0.495 \\
\hline \#\# b7sr & -0.364 & 0.186 & 0.619 & & -0.132 & -0.214 & 0.388 \\
\hline \multicolumn{8}{|l|}{ \#\# } \\
\hline \#\# & RC1 & $\mathrm{RC} 2$ & $\mathrm{RC} 4$ & RC5 & RC3 & RC6 & $\mathrm{RC7}$ \\
\hline \#\# ss loadings & 9.172 & 6.083 & 4.704 & 4.533 & 3.628 & 2.599 & 2.556 \\
\hline \#\# Proportion Var & 0.183 & 0.122 & 0.094 & 0.091 & 0.073 & 0.052 & 0.051 \\
\hline \#\# Cumulative Var & 0.183 & 0.305 & 0.399 & 0.490 & 0.562 & 0.614 & 0.666 \\
\hline
\end{tabular}


Table A4 (continuation). Robustness of the PCA rotation methods

\begin{tabular}{|c|c|c|c|c|c|c|}
\hline \multicolumn{7}{|c|}{ Varimax Rotation - 6 components } \\
\hline \#\# & $\mathrm{RC} 1$ & $\mathrm{RC} 2$ & RC4 & RC5 & RC3 & RC6 \\
\hline \#\# DEPOP.9111 & -0.385 & 0.192 & 0.497 & -0.531 & 0.136 & \\
\hline \#\# RESID.9111 & & 0.121 & 0.456 & -0.550 & 0.152 & \\
\hline \#\# d1 & 0.953 & -0.134 & -0.104 & 0.136 & & \\
\hline \#\# d2 & -0.913 & 0.116 & & -0.174 & & \\
\hline \#\# d3 & 0.946 & -0.127 & & 0.156 & & \\
\hline \#\# d4 & 0.920 & -0.119 & & 0.174 & & \\
\hline \#\# d5 & & -0.244 & & & & 0.232 \\
\hline \#\# d6 & 0.816 & -0.104 & & 0.118 & 0.129 & \\
\hline \#\# d7 & 0.866 & -0.111 & -0.199 & & & \\
\hline \#\# d8 & 0.893 & -0.114 & & 0.136 & & \\
\hline \#\# x0 & -0.115 & 0.275 & 0.107 & -0.538 & & 0.475 \\
\hline \#\# log_x0 & -0.226 & 0.223 & 0.123 & -0.583 & & 0.476 \\
\hline \#\# x2 & & & -0.134 & & & 0.833 \\
\hline \#\# x2b & & 0.107 & -0.151 & & & 0.846 \\
\hline \#\# x3 & & & & 0.880 & 0.197 & \\
\hline \#\# x3b & & & & 0.884 & 0.131 & 0.135 \\
\hline \#\# x4 & 0.515 & & 0.131 & 0.709 & & \\
\hline \#\# x4b & 0.482 & & 0.109 & 0.769 & & \\
\hline \#\# dens91 & -0.554 & & 0.286 & -0.200 & 0.178 & \\
\hline \#\# forei & & 0.223 & & 0.251 & 0.421 & \\
\hline \#\# born & & -0.294 & -0.646 & 0.189 & -0.236 & \\
\hline \#\# abroad & & 0.183 & 0.217 & 0.302 & 0.469 & \\
\hline \#\# men & & & & 0.446 & -0.414 & 0.124 \\
\hline \#\# educ1 & 0.408 & & -0.342 & 0.113 & -0.212 & \\
\hline \#\# educ2 & -0.461 & & 0.594 & & & \\
\hline \#\# educ3 & & & 0.761 & & & -0.128 \\
\hline \#\# activ & -0.185 & & & & -0.769 & \\
\hline \#\# emplo & & & & & -0.854 & \\
\hline \#\# unemp & -0.254 & -0.100 & & & 0.745 & \\
\hline \#\# income96 & 0.134 & 0.245 & 0.658 & & & \\
\hline \#\# income09 & -0.234 & & 0.691 & & -0.344 & \\
\hline \#\# ISDN & -0.434 & & 0.281 & & -0.239 & \\
\hline \#\# social & 0.237 & & 0.312 & & 0.237 & \\
\hline \#\# tour & -0.108 & -0.110 & 0.313 & 0.222 & & 0.182 \\
\hline \#\# work & -0.127 & 0.789 & 0.137 & & & \\
\hline \#\# emp1 & 0.631 & -0.161 & -0.320 & 0.126 & -0.573 & \\
\hline \#\# emp2 & -0.477 & -0.107 & & 0.258 & & 0.210 \\
\hline \#\# emp3 & -0.343 & 0.443 & 0.263 & -0.110 & 0.345 & \\
\hline \#\# emp4 & -0.397 & & -0.170 & -0.244 & 0.491 & -0.206 \\
\hline \#\# emp5 & -0.464 & & 0.509 & -0.131 & 0.499 & \\
\hline \#\# b1r & -0.116 & 0.924 & & & & \\
\hline \#\# b2r & -0.128 & 0.914 & 0.109 & & & \\
\hline \#\# b3r & -0.107 & 0.950 & & & & \\
\hline \#\# b4r & & 0.821 & & & & \\
\hline \#\# b5 & -0.199 & 0.111 & & 0.109 & & \\
\hline \#\# b6r & -0.131 & 0.931 & 0.117 & & & \\
\hline \#\# b7r & -0.302 & 0.285 & 0.606 & & -0.200 & -0.379 \\
\hline \#\# b7ir & 0.101 & 0.533 & 0.134 & & & -0.323 \\
\hline \#\# b7cr & -0.159 & 0.147 & 0.186 & -0.227 & & -0.421 \\
\hline \#\# b7sr & -0.368 & 0.150 & 0.682 & & -0.230 & -0.250 \\
\hline \multicolumn{7}{|l|}{ \#\# } \\
\hline \#\# & $\mathrm{RC} 1$ & $\mathrm{RC} 2$ & $\mathrm{RC} 4$ & RC5 & RC3 & RC6 \\
\hline \#\# ss loadings & 9.068 & 6.059 & 4.820 & 4.784 & 4.019 & 2.642 \\
\hline \#\# Proportion Var & 0.181 & 0.121 & 0.096 & 0.096 & 0.080 & 0.053 \\
\hline \#\# Cumulative Var & 0.181 & 0.303 & 0.399 & 0.495 & 0.575 & 0.628 \\
\hline
\end{tabular}


Table A4 (continuation). Robustness of the PCA rotation methods

\begin{tabular}{|c|c|c|c|c|c|c|c|c|}
\hline \multicolumn{9}{|c|}{ None Rotation - 8 components } \\
\hline \#\# & PC1 & PC2 & PC3 & PC4 & PC5 & PC6 & PC7 & PC8 \\
\hline \#\# DEPOP.9111 & 0.747 & & & 0.264 & -0.306 & 0.112 & & \\
\hline \#\# RESID.9111 & 0.338 & & & 0.383 & -0.508 & 0.167 & 0.138 & \\
\hline \#\# d1 & -0.878 & 0.267 & & 0.224 & -0.251 & & & \\
\hline \#\# d2 & 0.856 & -0.278 & & -0.223 & 0.170 & & & \\
\hline \#\# d3 & -0.858 & 0.286 & & 0.235 & -0.255 & & & \\
\hline \#\# d4 & -0.844 & 0.291 & & 0.211 & -0.231 & & & -0.120 \\
\hline \#\# d5 & -0.140 & -0.153 & & & & 0.275 & & -0.312 \\
\hline \#\# d6 & -0.701 & 0.266 & 0.108 & 0.228 & -0.280 & & 0.215 & \\
\hline \#\# d7 & -0.785 & 0.179 & & 0.157 & -0.344 & & & \\
\hline \#\# d8 & -0.814 & 0.270 & & 0.236 & -0.193 & & & -0.120 \\
\hline \#\# x0 & 0.372 & & -0.265 & -0.178 & -0.461 & 0.406 & & 0.130 \\
\hline \#\# $\log _{-} \mathrm{x} 0$ & 0.455 & & -0.315 & -0.164 & -0.408 & 0.425 & & 0.207 \\
\hline \#\# x2 & -0.152 & & -0.159 & -0.458 & & 0.679 & 0.108 & 0.274 \\
\hline \#\# x2b & -0.124 & & -0.150 & -0.505 & & 0.666 & & 0.266 \\
\hline \#\# x3 & -0.321 & 0.347 & 0.539 & -0.233 & 0.506 & & 0.108 & 0.115 \\
\hline \#\# x3b & -0.304 & 0.355 & 0.483 & -0.253 & 0.547 & & 0.112 & 0.103 \\
\hline \#\# x4 & -0.553 & 0.507 & 0.381 & & 0.278 & & & \\
\hline \#\# x4b & -0.564 & 0.500 & 0.392 & & 0.337 & 0.120 & & \\
\hline \#\# dens91 & 0.635 & -0.158 & 0.159 & & & & & -0.136 \\
\hline \#\# forei & & 0.291 & 0.382 & -0.220 & & & -0.405 & 0.382 \\
\hline \#\# born & -0.511 & -0.321 & -0.198 & -0.354 & 0.219 & -0.168 & 0.310 & -0.123 \\
\hline \#\# abroad & & 0.360 & 0.519 & & & & -0.515 & 0.384 \\
\hline \#\# men & -0.164 & 0.174 & -0.140 & & 0.538 & 0.146 & 0.215 & \\
\hline \#\# educ1 & -0.503 & & -0.237 & & & -0.124 & 0.283 & 0.332 \\
\hline \#\# educ2 & 0.639 & & 0.172 & 0.299 & 0.127 & 0.189 & -0.269 & -0.203 \\
\hline \#\# educ3 & 0.328 & 0.144 & 0.329 & 0.574 & & 0.210 & -0.263 & \\
\hline \#\# activ & 0.112 & & -0.629 & & 0.462 & & -0.395 & 0.104 \\
\hline \#\# emplo & & & -0.716 & 0.179 & 0.443 & & -0.345 & 0.142 \\
\hline \#\# unemp & 0.162 & -0.135 & 0.664 & -0.322 & -0.237 & & & -0.170 \\
\hline \#\# income96 & 0.226 & 0.430 & & 0.481 & & 0.200 & & \\
\hline \#\# income09 & 0.419 & & & 0.497 & 0.318 & 0.336 & 0.289 & \\
\hline \#\# ISDN & 0.429 & -0.101 & & 0.128 & 0.307 & 0.115 & 0.264 & \\
\hline \#\# social & & 0.252 & 0.220 & 0.245 & -0.210 & & -0.117 & 0.164 \\
\hline \#\# tour & & & 0.195 & 0.111 & 0.225 & 0.311 & & -0.149 \\
\hline \#\# work & 0.408 & 0.668 & -0.109 & -0.181 & & & & \\
\hline \#\# emp1 & -0.764 & & -0.497 & 0.116 & 0.161 & & -0.150 & \\
\hline \#\# emp2 & 0.256 & -0.165 & 0.233 & -0.238 & 0.332 & 0.204 & 0.271 & \\
\hline \#\# emp3 & 0.590 & 0.286 & 0.207 & -0.113 & -0.170 & & 0.104 & \\
\hline \#\# emp4 & 0.386 & -0.244 & 0.285 & -0.238 & -0.290 & -0.315 & 0.217 & 0.195 \\
\hline \#\# emp5 & 0.643 & & 0.510 & 0.145 & -0.158 & 0.131 & & -0.139 \\
\hline \#\# b1r & 0.464 & 0.722 & -0.268 & -0.234 & & -0.100 & & -0.239 \\
\hline \#\# b2r & 0.444 & 0.760 & -0.167 & -0.252 & & & & -0.170 \\
\hline \#\# b3r & 0.435 & 0.775 & -0.209 & -0.287 & & & & -0.220 \\
\hline \#\# b4r & 0.370 & 0.647 & -0.218 & -0.260 & -0.101 & & & -0.298 \\
\hline \#\# b5 & 0.132 & & & -0.158 & 0.161 & & & \\
\hline \#\# b6r & 0.497 & 0.735 & -0.236 & -0.197 & & -0.124 & & -0.120 \\
\hline \#\# b7r & 0.613 & 0.226 & & 0.499 & 0.196 & -0.116 & 0.267 & 0.230 \\
\hline \#\# b7ir & 0.206 & 0.484 & -0.137 & 0.144 & & -0.315 & 0.162 & 0.357 \\
\hline \#\# b7cr & 0.350 & & & 0.283 & & -0.317 & 0.437 & 0.363 \\
\hline \#\# b7sr & 0.614 & 0.140 & & 0.507 & 0.292 & & 0.148 & \\
\hline \multicolumn{9}{|l|}{ \#\# } \\
\hline \#\# & PC1 & PC2 & PC3 & PC4 & PC5 & PC6 & PC7 & PC8 \\
\hline \#\# ss loadings & 12.181 & 5.566 & 4.205 & 3.648 & 3.512 & 2.280 & 1.884 & 1.652 \\
\hline \#\# Proportion Var & 0.244 & 0.111 & 0.084 & 0.073 & 0.070 & 0.046 & 0.038 & 0.033 \\
\hline \#\# Cumulative Var & 0.244 & 0.355 & 0.439 & 0.512 & 0.582 & 0.628 & 0.666 & 0.699 \\
\hline
\end{tabular}


Table A4 (continuation). Robustness of the PCA rotation methods

\begin{tabular}{|c|c|c|c|c|c|c|c|c|}
\hline \multicolumn{9}{|c|}{ Promax Rotation - 8 components } \\
\hline \#\# & RC1 & $\mathrm{RC} 2$ & RC4 & RC5 & $\mathrm{RC} 3$ & RC7 & RC6 & RC8 \\
\hline \#\# DEPOP.9111 & -0.173 & & 0.459 & -0.403 & 0.118 & & & 0.196 \\
\hline \#\# RESID.9111 & 0.348 & & 0.459 & -0.473 & 0.191 & & 0.125 & 0.214 \\
\hline \#\# d1 & 1.000 & & & & & & & \\
\hline \#\# d2 & -0.924 & & & & & & & \\
\hline \#\# d3 & 1.009 & & & & 0.139 & & & \\
\hline \#\# d4 & 1.000 & & & & 0.137 & & & \\
\hline \#\# d5 & 0.188 & & & & & -0.219 & & -0.398 \\
\hline \#\# d6 & 0.936 & & & & 0.297 & -0.113 & & \\
\hline \#\# d7 & 0.920 & & -0.145 & -0.149 & 0.122 & & & \\
\hline \#\# d8 & 0.963 & & & & & & & \\
\hline \#\# x0 & & 0.136 & & -0.441 & & & 0.546 & \\
\hline \#\# log_x0 & -0.119 & & & -0.451 & & & 0.597 & \\
\hline \#\# x2 & & -0.103 & -0.116 & 0.180 & & & 0.901 & -0.129 \\
\hline \#\# x2b & & & -0.157 & 0.164 & & & 0.905 & -0.145 \\
\hline \#\# x3 & & & & 0.983 & 0.193 & 0.213 & & \\
\hline \#\# x3b & -0.109 & & & 0.989 & 0.140 & 0.176 & 0.123 & \\
\hline \#\# x4 & 0.442 & & 0.209 & 0.726 & & 0.224 & & \\
\hline$\# \# x 4 b$ & 0.398 & & 0.189 & 0.789 & & 0.214 & & \\
\hline \#\# dens91 & -0.390 & & 0.225 & -0.118 & 0.209 & -0.102 & & \\
\hline \#\# forei & -0.232 & & -0.150 & 0.306 & & 0.811 & 0.101 & \\
\hline \#\# born & & & -0.611 & 0.137 & & -0.463 & & \\
\hline \#\# abroad & -0.146 & -0.110 & 0.136 & 0.347 & & 0.945 & & \\
\hline \#\# men & & 0.117 & 0.131 & 0.471 & -0.208 & -0.292 & 0.101 & \\
\hline \#\# educ1 & 0.246 & -0.130 & -0.273 & 0.159 & & & 0.155 & 0.424 \\
\hline \#\# educ2 & -0.302 & & 0.590 & & -0.121 & & -0.123 & -0.278 \\
\hline \#\# educ3 & & -0.146 & 0.825 & & -0.102 & 0.257 & -0.148 & -0.149 \\
\hline \#\# activ & -0.411 & & & -0.132 & -0.997 & 0.117 & & \\
\hline \#\# emplo & -0.264 & & 0.137 & -0.157 & -1.047 & & & \\
\hline \#\# unemp & -0.151 & & -0.233 & 0.177 & 0.784 & & & -0.174 \\
\hline \#\# income96 & 0.328 & & 0.737 & 0.109 & & & & 0.160 \\
\hline \#\# income09 & & & 0.847 & 0.116 & -0.119 & -0.354 & & 0.145 \\
\hline \#\# ISDN & -0.291 & & 0.344 & & & -0.365 & & \\
\hline \#\# social & 0.263 & & 0.311 & & & 0.340 & & \\
\hline \#\# tour & & & 0.374 & 0.260 & & -0.133 & 0.112 & -0.186 \\
\hline \#\# work & -0.106 & 0.668 & & 0.184 & & 0.129 & & 0.200 \\
\hline \#\# emp1 & 0.444 & & -0.181 & & -0.598 & & & \\
\hline \#\# emp2 & -0.417 & & & 0.396 & 0.255 & -0.247 & 0.186 & \\
\hline \#\# emp3 & -0.171 & 0.386 & 0.143 & & 0.358 & & & \\
\hline \#\# emp4 & -0.415 & -0.130 & -0.311 & & 0.526 & & & 0.334 \\
\hline \#\# emp5 & -0.251 & & 0.424 & & 0.413 & 0.125 & & -0.158 \\
\hline \#\# b1r & & 1.021 & & & & & & \\
\hline \#\# b2r & & 0.964 & & & & & & \\
\hline \#\# b3r & & 1.039 & & & & & & \\
\hline \#\# b4r & & 0.974 & -0.106 & & & -0.130 & & -0.117 \\
\hline \#\# b5 & -0.237 & & & 0.170 & & & & \\
\hline \#\# b6r & & 0.941 & & & & & & \\
\hline \#\# b7r & -0.186 & & 0.686 & & -0.112 & & -0.142 & 0.564 \\
\hline \#\# b7ir & & 0.247 & 0.118 & & & 0.185 & & 0.606 \\
\hline \#\# b7cr & -0.128 & -0.157 & 0.222 & & 0.119 & -0.116 & -0.124 & 0.756 \\
\hline \#\# b7sr & -0.212 & & 0.778 & & -0.166 & -0.103 & -0.117 & 0.291 \\
\hline \multicolumn{9}{|l|}{ \#\# } \\
\hline \#\# & RC1 & $\mathrm{RC} 2$ & $\mathrm{RC} 4$ & RC5 & RC3 & $\mathrm{RC7}$ & RC6 & RC8 \\
\hline \#\# ss loadings & 8.814 & 5.744 & 5.361 & 4.920 & 4.208 & 2.823 & 2.569 & 2.294 \\
\hline \#\# Proportion Var & 0.176 & 0.115 & 0.107 & 0.098 & 0.084 & 0.056 & 0.051 & 0.046 \\
\hline \#\# Cumulative Var & 0.176 & 0.291 & 0.398 & 0.497 & 0.581 & 0.637 & 0.689 & 0.735 \\
\hline
\end{tabular}


Table A4 (continuation). Robustness of the PCA rotation methods

\begin{tabular}{|c|c|c|c|c|c|c|c|c|}
\hline \multicolumn{9}{|c|}{ Cluster Rotation - 8 components } \\
\hline \#\# & $\mathrm{RC} 1$ & $\mathrm{RC} 2$ & RC5 & $\mathrm{RC} 4$ & $\mathrm{RC} 3$ & RC7 & RC6 & RC8 \\
\hline \#\# DEPOP.9111 & -0.140 & & -0.450 & 0.457 & 0.138 & & 0.168 & 0.166 \\
\hline \#\# RESID.9111 & 0.366 & & -0.525 & 0.440 & 0.155 & & 0.224 & 0.177 \\
\hline \#\# d1 & 0.948 & & & & & & & \\
\hline \#\# d2 & -0.881 & & & & 0.145 & & & \\
\hline \#\# d3 & 0.947 & & & & & & & \\
\hline \#\# d4 & 0.909 & & & & & & & \\
\hline \#\# d5 & & & & 0.121 & & -0.226 & & -0.462 \\
\hline \#\# d6 & 0.850 & & & & 0.181 & & & \\
\hline \#\# d7 & 0.906 & & -0.150 & -0.167 & & & & \\
\hline \#\# d8 & 0.879 & & & & & & & -0.101 \\
\hline \#\# x0 & & 0.159 & -0.451 & & & & 0.618 & \\
\hline \#\# log_x0 & & & -0.457 & 0.102 & & & 0.667 & \\
\hline \#\# x2 & & & 0.212 & & & & 0.860 & -0.138 \\
\hline \#\# x2b & & & 0.191 & -0.116 & & & 0.870 & -0.144 \\
\hline \#\# x3 & -0.191 & & 0.965 & & 0.175 & 0.200 & & \\
\hline \#\# x3b & -0.231 & & 0.987 & & 0.120 & 0.163 & & \\
\hline \#\# x4 & 0.350 & & 0.715 & 0.166 & & 0.240 & & \\
\hline \#\# x4b & 0.283 & & 0.786 & 0.152 & & 0.225 & & \\
\hline \#\# dens91 & -0.469 & & -0.137 & 0.265 & 0.213 & -0.104 & & -0.128 \\
\hline \#\# forei & & & 0.216 & -0.108 & & 0.786 & & 0.161 \\
\hline \#\# born & & & 0.195 & -0.613 & & -0.485 & & \\
\hline \#\# abroad & & & 0.244 & 0.167 & & 0.928 & & 0.111 \\
\hline \#\# men & -0.190 & & 0.558 & & -0.229 & -0.294 & & \\
\hline \#\# educ1 & 0.359 & -0.121 & 0.162 & -0.339 & & & 0.127 & 0.453 \\
\hline \#\# educ2 & -0.410 & & & 0.607 & -0.128 & & & -0.322 \\
\hline \#\# educ3 & & -0.133 & & 0.802 & -0.140 & 0.275 & -0.130 & -0.191 \\
\hline \#\# activ & -0.303 & & & & -0.893 & & & \\
\hline \#\# emplo & -0.151 & & & & -0.950 & & & \\
\hline \#\# unemp & -0.229 & & & -0.119 & 0.737 & & & -0.174 \\
\hline \#\# income96 & 0.232 & 0.116 & & 0.672 & & & & 0.111 \\
\hline \#\# income09 & -0.206 & & 0.167 & 0.760 & -0.159 & -0.305 & & \\
\hline \#\# ISDN & -0.443 & & 0.132 & 0.307 & & -0.353 & & \\
\hline \#\# social & 0.324 & & & 0.301 & & 0.368 & & 0.117 \\
\hline \#\# tour & -0.184 & & 0.285 & 0.372 & & -0.124 & & -0.259 \\
\hline \#\# work & & 0.676 & 0.184 & & & 0.134 & & 0.248 \\
\hline \#\# emp1 & 0.502 & -0.144 & & -0.252 & -0.597 & & & \\
\hline \#\# emp2 & -0.598 & & 0.411 & & 0.244 & -0.254 & 0.122 & -0.122 \\
\hline \#\# emp3 & -0.209 & 0.423 & & 0.183 & 0.348 & & & \\
\hline \#\# emp4 & -0.264 & & -0.197 & -0.261 & 0.587 & & & 0.376 \\
\hline \#\# emp5 & -0.343 & & -0.112 & 0.486 & 0.384 & 0.133 & & -0.193 \\
\hline \#\# b1r & & 0.992 & & & & & & \\
\hline \#\# b2r & & 0.944 & 0.126 & & & & & \\
\hline \#\# b3r & & 1.013 & & & & & & \\
\hline \#\# b4r & & 0.942 & & & & -0.141 & & \\
\hline \#\# b5 & -0.245 & & 0.181 & & & & & 0.121 \\
\hline \#\# b6r & & 0.924 & & & & & & \\
\hline \#\# b7r & -0.166 & & & 0.578 & & & -0.116 & 0.524 \\
\hline \#\# b7ir & 0.239 & 0.275 & & & & 0.221 & & 0.666 \\
\hline \#\# b7cr & & -0.104 & -0.104 & 0.131 & 0.188 & & & 0.750 \\
\hline \#\# b7sr & -0.290 & & 0.101 & 0.692 & -0.145 & & -0.104 & 0.223 \\
\hline \multicolumn{9}{|l|}{ \#\# } \\
\hline \#\# & $\mathrm{RC} 1$ & $\mathrm{RC} 2$ & RC5 & $\mathrm{RC} 4$ & $\mathrm{RC} 3$ & RC7 & RC6 & RC8 \\
\hline \#\# ss lo & 8.417 & 5.539 & 5.028 & 4.781 & 3.677 & 2.748 & 2.568 & 2.498 \\
\hline \#\# Proportion Var & 0.168 & 0.111 & 0.101 & 0.096 & 0.074 & 0.055 & 0.051 & 0.050 \\
\hline \#\# Cumulative Var & 0.168 & 0.279 & 0.380 & 0.475 & 0.549 & 0.604 & 0.655 & 0.705 \\
\hline
\end{tabular}


Table A4 (continuation). Robustness of the PCA rotation methods

\begin{tabular}{|c|c|c|c|c|c|c|c|c|}
\hline & Quartir & nax Rota & tion -7 & compone & & & & \\
\hline \#\# & $\mathrm{RC} 1$ & $\mathrm{RC} 2$ & $\mathrm{RC} 4$ & RC5 & $\mathrm{RC} 3$ & RC6 & $\mathrm{RC7}$ & RC8 \\
\hline \#\# DEPOP.9111 & -0.466 & 0.170 & 0.474 & -0.463 & 0.182 & & & 0.157 \\
\hline \#\# RESID.9111 & & 0.108 & 0.460 & -0.511 & 0.219 & 0.112 & & 0.185 \\
\hline \#\# d1 & 0.974 & -0.104 & & & & & & \\
\hline$\# \# \mathrm{~d} 2$ & -0.933 & & & & & & & \\
\hline \#\# d3 & 0.966 & & & & & & & \\
\hline \#\# d4 & 0.949 & & & & & & & \\
\hline \#\# d5 & 0.103 & -0.150 & & & & & -0.178 & -0.383 \\
\hline \#\# d6 & 0.835 & & & & 0.198 & & & \\
\hline \#\# d7 & 0.881 & & -0.148 & & & & & \\
\hline \#\# d8 & 0.919 & & & & & & & \\
\hline \#\# x0 & -0.162 & 0.252 & & -0.477 & & 0.549 & & \\
\hline \#\# log_x0 & -0.276 & 0.183 & 0.112 & -0.501 & & 0.590 & & \\
\hline \#\# x2 & & & -0.129 & 0.109 & & 0.876 & & \\
\hline$\# \#$ x2b & & & -0.155 & & & 0.885 & & \\
\hline \#\# x3 & 0.131 & & & 0.892 & 0.141 & & 0.113 & \\
\hline \#\# x3b & 0.113 & & & 0.899 & & & & \\
\hline \#\# x4 & 0.549 & & 0.135 & 0.675 & & & 0.174 & \\
\hline \#\# x4b & 0.527 & & 0.111 & 0.736 & & & 0.153 & \\
\hline \#\# dens91 & -0.568 & & 0.247 & -0.150 & 0.229 & & & -0.113 \\
\hline \#\# forei & & 0.118 & -0.123 & 0.240 & 0.117 & & 0.706 & \\
\hline \#\# born & 0.193 & -0.267 & -0.581 & 0.190 & & & -0.473 & \\
\hline \#\# abroad & & & 0.121 & 0.273 & 0.124 & & 0.839 & \\
\hline \#\# men & & & & 0.456 & -0.298 & & -0.344 & \\
\hline \#\# educ1 & 0.422 & & -0.277 & 0.133 & -0.166 & 0.143 & -0.101 & 0.439 \\
\hline \#\# educ2 & -0.496 & 0.107 & 0.540 & & & -0.140 & 0.113 & -0.320 \\
\hline \#\# educ3 & -0.124 & & 0.720 & & & -0.195 & 0.267 & -0.215 \\
\hline \#\# activ & -0.200 & & & & -0.865 & & & \\
\hline \#\# emplo & & & & & -0.929 & & & \\
\hline \#\# unemp & -0.232 & & -0.143 & 0.130 & 0.738 & & 0.113 & -0.182 \\
\hline \#\# income96 & & 0.245 & 0.660 & & & & & 0.104 \\
\hline \#\# income09 & -0.232 & & 0.730 & & -0.153 & & -0.336 & \\
\hline \#\# ISDN & -0.410 & & 0.304 & & & & -0.359 & \\
\hline \#\# social & 0.180 & & 0.286 & & 0.139 & & 0.345 & \\
\hline \#\# tour & & & 0.309 & 0.234 & & & -0.131 & -0.208 \\
\hline \#\# work & -0.158 & 0.746 & 0.108 & 0.117 & & & 0.127 & 0.203 \\
\hline \#\# emp1 & 0.658 & -0.172 & 0.249 & & -0.602 & & & \\
\hline \#\# emp2 & -0.414 & & & 0.331 & 0.177 & 0.180 & -0.274 & \\
\hline \#\# emp3 & -0.372 & 0.450 & 0.212 & & 0.362 & & & \\
\hline \#\# emp4 & -0.432 & & -0.203 & -0.162 & 0.495 & & & 0.316 \\
\hline \#\# emp5 & -0.503 & & 0.435 & & 0.479 & & 0.184 & -0.207 \\
\hline \#\# b1r & -0.128 & 0.956 & & & & & & \\
\hline \#\# b2r & -0.140 & 0.931 & & & & & & \\
\hline \#\# b3r & -0.115 & 0.977 & & & & & & \\
\hline \#\# b4r & & 0.871 & & & & & & \\
\hline \#\# b5 & -0.184 & & & 0.140 & & & & \\
\hline \#\# b6r & -0.158 & 0.933 & & & & & & \\
\hline \#\# b7r & -0.365 & 0.223 & 0.627 & & -0.109 & -0.187 & & 0.477 \\
\hline \#\# b7ir & & 0.423 & 0.145 & & & -0.105 & 0.174 & 0.573 \\
\hline \#\# b7cr & -0.216 & & 0.227 & -0.141 & & -0.152 & -0.108 & 0.691 \\
\hline \#\# b7sr & -0.409 & 0.146 & 0.692 & & -0.141 & -0.159 & -0.106 & 0.209 \\
\hline \multicolumn{9}{|l|}{ \#\# } \\
\hline \#\# & RC1 & $\mathrm{RC} 2$ & RC4 & RC5 & RC3 & RC6 & RC7 & RC8 \\
\hline \#\# ss loadings & 9.759 & 5.847 & 4.459 & 4.353 & 3.638 & 2.495 & 2.382 & 1.995 \\
\hline \#\# Proportion Var & 0.195 & 0.117 & 0.089 & 0.087 & 0.073 & 0.050 & 0.048 & 0.040 \\
\hline \#\# Cumulative Var & 0.195 & 0.312 & 0.401 & 0.488 & 0.561 & 0.611 & 0.659 & 0.699 \\
\hline
\end{tabular}




\section{References}

Akgün, A. A., Baycan, T., \& Nijkamp, P. (2015). Rethinking on sustainable rural development. European Planning Studies, 23(4), 678-692. DOI: https://doi.org/10.1080/09654313.2014.945813

Artz, G. M., Cho, I., Guo, Z., Kim, Y., Orazem, P. F., \& Yu, L. (2015). Eighty years of research on rural economic development, agglomeration, migration, commuting, income, innovation, and entrepreneurship: The Iowa State human capital tradition. AgBioForum, 18(3), 243-251.

Retrieved from: http://www.agbioforum.org/v18n3/v18n3a02-artz.htm

Barbut, L. (2009). L'évaluation ex post du PDRN: un regard instructif sur le passé pour améliorer l'avenir. Notes et Études Socio-Économiques, 33, 7-39. Retrieved from: http://37.235.92.116/IMG/pdf nese091133A1.pdf

Bryden, J., \& Munro, G. (2000). New approaches to economic development in peripheral rural regions. Scottish Geographical Journal, 116(2), 111-124. DOI: https://doi.org/10.1080/00369220018737085

Bureau, J. C. (2016). Workshop 1: Jobs, growth and investment in the wider rural economy. Cork 2.0 Conference on Rural Development, 5th Sept 2016, Cork, Ireland.

Retrieved from: https://enrd.ec.europa.eu/cork-20-and-future-rural-development en

Collantes, F., Pinilla, V., Sáez, L A., \& Silvestre, J. (2014). Reducing depopulation in rural Spain: The impact of immigration. Population, Space and Place, 20(7), 606-621. DOI: https://doi.org/10.1002/psp.1797

Eguía, B., \& Aldaz, L. (2019). Valoración de la vulnerabilidad demográfica y económica a escala local. El caso del País Vasco. Scripta Nova. Revista Electrónica de Geografía y Ciencias Sociales, XXIII(628). DOI: https://doi.org/10.1344/sn2019.23.22717

Eliasson, K., Westlund, H., \& Johansson, M. (2015). Determinants of net migration to rural areas, and the impacts of migration on rural labour markets and self-employment in rural Sweden. European Planning Studies, 23(4), 693-709. DOI: https://doi.org/10.1080/09654313.2014.945814

Elshof, H., van Wissen, L., \& Mulder, C. H. (2014). The self-reinforcing effects of population decline: An analysis of differences in moving behaviour between rural neighbourhoods with declining and stable populations. Journal of Rural Studies, 36, 285-299. DOI: https://doi.org/10.1016/j.jrurstud.2014.09.006

European Commission. (2013). Rural Development in the European Union. Statistical and Economic InformationReport 2013. Brussels, Belgium: European Commission. Directorate-General for Agriculture and Rural Development.

Eurostat. (2011) The degree of urbanization (DEGURBA). Luxembourg, Luxembourg: Eurostat. Retrieved from: http://ec.europa.eu/eurostat/ramon/miscellaneous/index.cfm?TargetUrl=DSP_DEGURBA

Fernández Leiceaga, X., \& López Iglesias, E. (2000). Estrutura económica de Galiza. Santiago de Compostela: Laiovento.

Fernández, M., \& Peón, D. (2017). Desafios dunha sociedade avellentada e en declive: desequilibrios territoriais e prestacion de servizos. Foro Económico de Galicia, Documento 20/2017.

Figueiredo, E. (2009). One rural, two visions: Environmental issues and images on rural areas in Portugal. Journal of European Countryside, 1(1), 9-21. DOI: https://doi.org/10.2478/v10091-009-0002-8

IGE. (2011). Clasificación do grao de urbanización das parroquias e concellos galegos (GU 2011). Santiago de Compostela: Instituto Galego de Estatística.

Retrieved from: http://www.ige.eu/web/mostrar paxina.jsp?paxina=003003001\&idioma=gl

IGE. (2016). Clasificación das parroquias e concellos galegos segundo o grao de urbanización (GU 2016). Santiago de Compostela: Instituto Galego de Estatística.

Retrieved from: http://www.ige.eu/web/mostrar paxina.jsp?paxina=003003001\&idioma=gl

Johnson, R. A., \& Wichern, D. W. (2014). Applied multivariate statistical analysis, vol. 4. Englewood Cliffs, NJ: Prentice-Hall.

Li, M., Goetza, S. J., Partridge, M., \& Fleming, D.A. (2016). Location determinants of high-growth firms. Entrepreneurship and Regional Development, 28(1-2), 97-125.

DOI: https://doi.org/10.1080/08985626.2015.1109003

López Iglesias, E. (1995). Demografía e estruturas agrarias. Análise da dinámica demográfica e das mudanças nas estruturas fundiárias da agricultura galega, 1950-1993. Santiago de Compostela: Universidade de Santiago de Compostela.

López Iglesias, E. (2013). A gobernanza e xestión do medio rural galego a comezos do século XXI: Reflexións e propostas para o debate. In R. Rodríguez González (Coord.), Galicia, un mundo rural vivo (pp. 130-147). Lalín (Pontevedra): Universidad Internacional Menéndez Pelayo / Concello de Lalín. Retrieved from: https://lalin.gal/files/Galicia\%20un\%20mundo\%20rural\%20vivo\%20baja.pdf 
López Iglesias, E., Peón, D., \& Rodríguez Álvarez, J. (2018). Mobility innovations for sustainability and cohesion of rural areas: A transport model and public investment analysis for Valdeorras (Galicia, Spain). Journal of Cleaner Production, 172, 3520-3534. DOI: https://doi.org/10.1016/i.jclepro.2017.05.149

Marsden, T., \& Sonnino, R. (2008). Rural development and the regional state: Denying multifunctional agriculture in the UK. Journal of Rural Studies, 24, 422-431. DOI: https://doi.org/10.1016/i.jrurstud.2008.04.001

Martínez Filgueira, X., Peón, D., \& López Iglesias, E. (2017). Intra-rural divides and regional planning within regions in demographic decline. Analysis of a traditional emigration region (Galicia, Spain). European Planning Studies, 25(7), 1237-1255. DOI: https://doi.org/10.1080/09654313.2017.1319465

Peón, D., \& Martínez Filgueira, X. (2019). Determinants of investing in innovative activities by agri-food and KIBS firms in rural areas: An exploratory analysis. Journal of Small Business Management. DOI: https://doi.org/10.1111/isbm.12513

Míguez Macho, L. (2013). Gobierno y gestión del medio rural en Galicia. La reforma de la administración local. In R. Rodríguez González (Coord.), Galicia, un mundo rural vivo (pp. 148-159). Lalín (Pontevedra): Universidad Internacional Menéndez Pelayo / Concello de Lalín.

Retrieved from: https://lalin.gal/files/Galicia\%20un\%20mundo\%20rural\%20vivo\%20baja.pdf

Phelan, C., \& Sharpley, R. (2011). Exploring agritourism entrepreneurship in the UK. Tourism Planning \& Development, 8(2), 121-136. DOI: https://doi.org/10.1080/21568316.2011.573912

Revelle, W. (2017). Psych: Procedures for personality and psychological research. Version $=1.75$. Evanston, IL: Northwestern University. Retrieved from: https://CRAN.R-project.org/package=psych

Rizzo, A. (2016). Declining, transition and slow rural territories in southern Italy: Characterizing the intra-rural divides. European Planning Studies, 24(2), 231-253. DOI: https://doi.org/10.1080/09654313.2015.1079588

Salvati, L., \& Carlucci, M. (2016). Patterns of sprawl: The socioeconomic and territorial profile of dispersed urban areas in Italy. Regional Studies, 50(8), 1346-1359. DOI: https://doi.org/10.1080/00343404.2015.1009435

Sánchez-Zamora, P., Gallardo-Cobos, R., \& Ceña-Delgado, F. (2014). Rural areas face the economic crisis: Analyzing the determinants of successful territorial dynamics. Journal of Rural Studies, 35, 11-25.

DOI: https://doi.org/10.1016/j.jrurstud.2014.03.007

Smailes, P. J., Argent, N., \& Griffin, L.C. (2002). Rural population density: Its impact on social and demographic aspects of rural communities. Journal of Rural Studies, 18, 385-404. DOI: https://doi.org/10.1016/S0743-0167(02)00033-5

Spoor, M. (2013). Multidimensional social exclusion and the 'rural-urban divide' in Eastern Europe and Central Asia. Sociologia Ruralis, 53(2), 139-157. DOI: https://doi.org/10.1111/soru.12008

Stephens, H. M., Partridge, M. D., \& Faggian, A. (2013). Innovation, entrepreneurship and economic growth in lagging regions. Journal of Regional Science, 53(5), 778-812. DOI: https://doi.org/10.1111/jors.12019

Xunta de Galicia. (2013). Plan para a dinamización demográfica de Galicia 2013-2016, Horizonte 2020. Santiago de Compostela: Xunta de Galicia. Consellería de Presidencia, AA.PP. e Xustiza. Retrieved from: http://www.xunta.es/c/document library/get file?folderId=577713\&name=DLFE-19604.pdf

Xunta de Galicia. (2014). Diagnóstico de situación socioeconómica e territorial de Galicia para a elaboración dos POs FEDER e FSE Galicia 2014-2020. Santiago de Compostela: Xunta de Galicia. Consellería de Facenda. Dirección Xeral de Planificación e Orzamentos. Retrieved from: http://www.conselleriadefacenda.es/documents/10433/1347376/Diagnostico-Socioeconomico-Galiciagal.pdf/a2b3ac61-d536-4058-9346-d3d0e18fb752 